\title{
Pulled, Pushed and Persuaded: Explaining Women's Mobilization into the Salvadoran Guerrilla Army
}

\section{Citation}

Viterna, Jocelyn. 2006. Pulled, pushed and persuaded: Explaining women's mobilization into the Salvadoran guerrilla army. American Journal of Sociology 112, no. 1: 1-45.

\section{Published Version}

http://dx.doi.org/10.1086/502690

\section{Permanent link}

http://nrs.harvard.edu/urn-3:HUL.InstRepos:3203776

\section{Terms of Use}

This article was downloaded from Harvard University's DASH repository, and is made available under the terms and conditions applicable to Other Posted Material, as set forth at http:// nrs.harvard.edu/urn-3:HUL.InstRepos:dash.current.terms-of-use\#LAA

\section{Share Your Story}

The Harvard community has made this article openly available. Please share how this access benefits you. Submit a story.

Accessibility 


\title{
Pulled, Pushed, and Persuaded: Explaining Women's Mobilization into the Salvadoran Guerrilla Army ${ }^{1}$
}

\author{
Jocelyn S. Viterna \\ Tulane University
}

\begin{abstract}
Using a rare representative sample of grassroots activists and nonactivists, this study identifies three paths that consistently led Salvadoran women to involvement in the FMLM guerrilla army: politicized guerillas, reluctant guerillas, and recruited guerillas. These mobilization paths arose from the patterned intersections of individual-level biographies, networks, and situational contexts. The implications of these findings extend beyond studies of revolutionary activism to analyses of microlevel mobilization in general. Activists are heterogeneous and often follow multiple paths to the same participation outcome. Capturing these multiple paths is imperative for generating theoretically sound explanations of mobilization that are also empirically effective in distinguishing activists from nonactivists.
\end{abstract}

Popular support is often considered the sine qua non of revolution (Wickham-Crowley 1992, p. 52). Nevertheless, there is little consensus among scholars about which causal factors are most important for generating popular mobilization (Kriger 1992). Some scholars portray popular participants as aggrieved individuals who become mobilized when structural conditions-for example, weak states, elite divisions, agrarian arrange-

\footnotetext{
${ }^{1}$ This project was funded with a Fulbright-Hays Fellowship from the U.S. Department of Education, an International Pre-dissertation Fellowship from the Social Science Research Council, support from the Indiana University Department of Sociology, and the P.E.O. Scholars Program. Sections of this article were presented at the 2003 and 2004 meetings of the American Sociological Association and at Tulane University. I thank Jason Beckfield, Kent Redding, Rob Robinson, Clem Brooks, Sheldon Stryker, Amy Hite, Katy Fallon, Doug Massey, and the AJS reviewers for their helpful comments. I also thank the many Salvadorans who participated in this project. Direct correspondence to Jocelyn Viterna, Department of Sociology, Tulane University, 220 Newcomb Hall, New Orleans, Louisiana 70118-5698. E-mail: jviterna@tulane.edu
}

(C) 2006 by The University of Chicago. All rights reserved. 0002-9602/2006/11201-0001\$10.00 
American Journal of Sociology

ments, or socioeconomic dislocations-are conducive to activism (Goldstone 1991; Paige 1975; Scott 1976; Skocpol 1979). For others, popular participants are rational actors who see opportunities for personal gain through revolutionary activism (Migdal 1974; Popkin 1979). Some scholars portray grassroots participants as identifying deeply with the ideals and goals of the movement because of their preexisting network memberships (Bearman 1993; Gould 1995; Pfaff 1996; Wickham-Crowley 1992). Still others depict participants as unwilling supporters of the cause, coerced to participate by threats of harm, denial of needed goods, or a lack of options to avoid activism (Goodwin 2001; Kriger 1992; Loveman 1998).

Yet, of the many individuals experiencing structural changes, of the many individuals in position to benefit from revolutionary activism, of the many individuals embedded in identity-molding mobilizing networks, and of the many individuals caught in coercive situations, only a few actually participate in revolutionary movements. Herein lies the dilemma: if the characteristics that explain activism are shared by activists and nonactivists, then how can these characteristics be the critical causal factors behind popular mobilization? If they are not, what additional—or alternative-factors explain why some, but not all, members of a group or network take part in high-risk revolutionary activism?

Questions about the causes of revolutionary mobilization remain unresolved because mobilization scholars generally seek the one causal factor or set of factors that "typically" leads individuals to activism. These explanations assume that activists are a largely homogenous group who generally follow one path to participation. But activists are heterogeneous (McAdam 1992; Wiltfang and McAdam 1991) and, as I demonstrate, can follow strikingly different paths to the same mobilization outcome. For example, the same causal factor that promotes mobilization in some people may actually inhibit mobilization in others. In this case, searching for the "typical" mobilization pattern obscures an important causal factor because its contradictory effects cannot be captured in a generalized explanation of all activism. These generalized explanations can therefore lead to inaccurate explanations of mobilization and distort our understanding of broader revolutionary processes.

In this article, I develop a novel theoretical approach for analyzing microlevel mobilization that complements mesolevel and macrocomparative studies. I argue that there are multiple, conjunctural causes of mobilization, even among individuals embedded within similar identityproducing networks and within similar structural contexts. These multiple paths to participation arise from the patterned interaction of individuallevel biography, networks, and situational context. Because mobilization processes are patterned, scholars can identify the different paths that 
individuals follow to participation while still prioritizing parsimonious explanations. My analysis shows that distinguishing microlevel variation in participation processes yields more accurate theories of high-risk activism and, in turn, improves our macrolevel understanding of the causes, successes, failures, and unintended consequences of popular revolutionary mobilization.

The case of women revolutionaries in El Salvador illustrates the utility of this approach. In the 1980s, thousands of Salvadoran women joined the Farabundo Marti National Liberation Front (FMLN), a revolutionary guerrilla army engaged in combat with the oppressive Salvadoran state. These women, like their counterparts around the world, defied patriarchal traditions, abandoned their homes and families, and became militant members of rural guerrilla insurgencies. ${ }^{2}$ By analyzing the multiple paths that Salvadoran women followed to the guerrilla camps, I refine existing explanations of women's revolutionary participation and suggest how these new insights may have important implications for macrolevel processes such as democratization and broader transformations in gendered rights and relations.

My conclusions are based on analysis of rich data from in-depth interviews with 82 female rank-and-file guerrilla combatants, guerrilla supporters, and nonparticipants in rural El Salvador. These data have two key advantages. First, they include the experiences of the grassroots, whereas most mobilization studies focus solely on movement leadership. Second, they allow for comparisons between activists and similarly situated nonactivists, whereas most studies sample on the dependent variable and omit nonactivists. This rare representative sample of activists and nonactivists is uniquely suited to the identification of the multiple paths to activism that deepen sociological understandings of mobilization.

\section{THEORIZING MICROLEVEL MOBILIZATION PROCESSES IN REVOLUTIONARY MOVEMENTS}

Scholars of revolution typically identify the macrolevel conditions conducive to mobilizing popular support. Many suggest that the revolutionary potential of aggrieved peasants is consistently present across place and time and becomes activated when certain political, historical, or economic conditions emerge. For example, they find that modernization and com-

\footnotetext{
${ }^{2}$ In Latin America alone, large numbers of women have participated in left-wing guerrilla movements in Nicaragua, Guatemala, the Chiapas (Mexico), Colombia, and Peru. Around the world, women have been militant, antistate activists in such diverse nations as Russia (in Chechnya), Eritrea, Iraq (especially the Kurdish region), Nepal, Sri Lanka, and Zimbabwe.
} 
American Journal of Sociology

mercialization bring institutional imbalances in society and result in weakened states (Skocpol 1979, 1994), a disrupted "moral economy" (Scott 1976), or increased participation incentives for rational, cost-calculating individuals (Popkin 1979). Others search for the group most likely to become revolutionary and argue, for example, that landless peasants (Paige 1975), or landowning middle peasants (Wolf 1969), are most likely to revolt. Macrolevel studies thus answer important questions about where and when revolutions may occur, but cannot explain why most individuals embedded in these "revolutionary" social locations or political-historical contexts do not, in fact, revolt. Thus, macrolevel models only take us so far in understanding the causes of revolution.

Scholars employing network analysis to explain revolutionary mobilization help connect macrolevel contexts to microlevel mobilization processes, as individuals interpret their larger social context through the networks in which they are embedded (Calhoun 1991). Peter Bearman (1993), for example, demonstrates how religious rhetoric in England created new social networks among elites, and that these new networks corresponded with revolutionary activity. Steven Pfaff (1996) analyzes the role of small-scale social networks in generating the peaceful revolution against the communist regime in East Germany in 1989. Timothy Wickham-Crowley (1992) argues that political, religious, and family networks were critical for mobilizing Latin Americans into leftist guerrilla movements. Roger Gould (1995) demonstrates that the spatial proximity of individuals within a network is also critical to their mobilization.

Network analyses of revolutionary participation parallel a long tradition in the social movement literature that argues interests alone cannot move people to participate in movements (Briet, Klandermans, and Kroon 1987; Henig 1982; Klandermans 1984; Olson 1965; Walsh 1988). ${ }^{3}$ Rather, interests must be embedded in structured social relations that highlight them as important and worthy of action (Emirbayer and Goodwin 1994; Stryker 2000). A number of empirical studies demonstrate the importance of preexisting networks for mobilizing social action at the microlevel (see, e.g., Briet et al. 1987; Fernandez and McAdam 1988; Gould 1995; Kim and Bearman 1997; Klandermans and Oegema 1987; McAdam 1986;

\footnotetext{
${ }^{3}$ Specifically, interest-based explanations cannot explain why some injustices lead to action and others do not, or why some aggrieved individuals participate in movements while others sit back and allow the activists to fight for all similarly aggrieved people (i.e., Olson's [1965] "free-rider" problem).
} 
McAdam and Paulsen 1993; Snow, Zurcher, and Ekland-Olson 1980). ${ }^{4}$ Such networks are particularly important for mobilization into high-risk forms of collective action, because a high degree of trust helps counteract the selective disincentives to participate in dangerous activities (della Porta 1988; Loveman 1998; McAdam 1986; Morris 1984).

Problems arise, however, because social network studies, like macrolevel studies of revolutionary mobilization, tend to be overly deterministic (McAdam 2000, p. xii). Movement participants are traced to a common network, but the failure of others embedded within the same network to participate is seldom acknowledged or analyzed.

Social psychological theories of identity-based mobilization processes provide insight into why networks mobilize some, but not all, of their members (Emirbayer and Goodwin 1994; McAdam 2000; Stryker 2000). According to these theories, individuals must develop a salient "participation identity" prior to mobilizing; that is, being a participant must become so important to a person's sense of self that to not participate would cause psychological and emotional harm. In addition, these scholars demonstrate that multiple identities are always competing for salience, even among people embedded in a common network. For example, a person's identity as "mother" may compete with a potential movement participation identity, especially if participation in the movement could jeopardize the woman's ability to be a good mother, and therefore her identity as a mother. Both identities may be important to the woman's sense of self, and both identities arise from social networks, but it is the interaction of these network-based identities with each other and with still other competing identities that determines whether the participation identity becomes salient enough to result in action (Stryker 2000). Being in a participation-supporting network therefore increases an individual's probability of mobilization, but does not guarantee it.

Very few studies model empirically the effects of overlapping networks on mobilization decisions. Of particular note, McAdam and Paulsen (1993) compared the social ties of both participants and nonparticipants in the Freedom Summer movement. They find that social ties inhibit as well as promote high-risk activism, and that intimate social ties are of greater importance for mobilization than more distant social ties. They also find

\footnotetext{
${ }^{4}$ Interests, especially categorical interests such as class, race, and gender, remain central to the concept of mobilizing networks. However, they are usually in combination with more finite social organizations. For example, Tilly's (1978) adaptation of Harrison White's CATNET table shows how categorical membership can intersect with social network patterns to create extraordinary collective action potential, and McAdam's (1992) analysis of the Student Nonviolent Coordinating Committee found that gender significantly affected recruitment decisions by movement leaders within targeted recruitment networks.
} 
American Journal of Sociology

that a person's "biographical availability," as determined by their education, gender, income, age, marital status, and occupation, affects participation decisions. People with fewer family and work responsibilities are more likely to participate. Nepstad and Smith (1999) tested the McAdam and Paulsen model with similar data from the high-risk Nicaragua Exchange movement. They confirm the importance of network ties, but question the importance of biographical availability; many respondents participated despite biographical barriers to mobilization.

Combining these findings with social psychological theories, I suggest that micro-level mobilization into high-risk activism can be modeled according to the following theoretical equation:

net influence of all networks -

the net influence of all biographical barriers $=$

the probability of high-risk activism,

where the first factor is the sum of a number of networks, each with its own influence on the participation identity in question. Some of these networks may positively support the identity of the participant, while others may reject participation (McAdam and Paulsen 1993). The magnitude of each network's influence on the emergence of a salient participation identity increases or decreases according to (1) the number of social ties encompassed in the network, and (2) the emotional strength and spatial proximity of these ties (Stryker 2000; Gould 1995). The first factor in the equation, the net influence of all network ties, is a necessary requirement for mobilization; a person cannot be moved to activism without meaningful network ties that support the identity of the participant. The impact of the second factor is debated; biographical barriers to participation may be overcome in cases where the individual's participation identity is salient enough to overcome competing identities.

\section{THEORIZING MICROLEVEL MOBILIZATION PROCESSES FOR WOMEN GUERRILLAS}

During the 1970s and 1980s, the number of women joining high-risk, militant, and indeed "masculine" revolutionary campaigns in Latin America increased dramatically. ${ }^{5}$ To illustrate: when the FMLN guerrilla army laid down its weapons and reorganized as a political party in El Salvador under the 1992 peace accords, fully 30\% of its approximately 13,000 of-

${ }^{5}$ For discussions of how waging war is a gendered process, see El-Bushra and Piza Lopez (1994), El-Bushra and Mukarubuga (1995), Enloe (1990), Skaine (1999), Wechsler Segal (1995), and Wickham-Crowley (1992, pp. 21-23). 


\section{Women's Mobilization}

ficially "demobilized" members were women (Luciak 2001; Vázquez, Ibáñez, Murguialday 1996). In Nicaragua and Guatemala, women were also estimated to make up $30 \%$ of the guerrilla armies (Chinchilla 1983; New Americas Press 1989; Thomson 1986), and in Peru, one-half of all Sendero Luminoso combatants were estimated to be female (McClintock quoted in Wickham-Crowley 1992). Furthermore, women, while never gaining equal status to men, did occupy significant leadership roles in guerrilla armies, including as battalion commanders and political liaisons (Chinchilla 1983; Reif-Lobao 1986; Ueltzen 1993). Several all-female units fought in direct combat with all-male, highly trained government forces (Saywell 1985; Thomson 1986).

To date, scholars have questioned why women entered guerrilla armies in the 1970s and 1980s and not in earlier movements of the 1950s and 1960s. ${ }^{6}$ They answer that changes in Latin American social and economic structures led to men's out-migration and eventual abandonment of their families, and to a corresponding increase in the number of impoverished female heads of household (Kampwirth 2002; Mason 1992; Reif-Lobao 1986, 1998). ${ }^{7}$ Women responded by moving into the paid labor force and mobilizing their communities around specifically women's interests (e.g., child care or familial nutritional needs). These new experiences in the labor force and in community politics increased women's contact with individuals and issues outside of the family and thus increased their potential for revolutionary mobilization.

All scholars highlight how changing structural conditions pushed women into new public roles, but early studies disagree on the catalyst that encouraged newly active women to join guerrilla armies. Reif-Lobao $(1986,1998)$ argues that new revolutionary ideologies combined with the global diffusion of feminist thought and encouraged political groups' re-

\footnotetext{
${ }^{6}$ According to Wickham-Crowley (1992), very few women became involved in the "first wave" of antigovernment guerrilla armies of the 1950s and 1960s, and those who did were largely relegated to support roles for male combatants. By the "second wave" movements of the 1970s and 1980s, however, women's participation differed substantially from the earlier movements in both number and in form. Wickham-Crowley states that "in no other fashion does the second wave of guerrillas differ so thoroughly from the first wave" than through the burgeoning numbers of women in their ranks (Wickham-Crowley 1992, p. 215).

${ }^{7}$ Reif-Lobao (1986, 1998) analyzed women guerrillas in Cuba, Colombia, Uruguay, Nicaragua, and El Salvador; Mason (1992) compared women's guerrilla activism in Nicaragua and El Salvador; and Kampwirth (2002) interviews women revolutionaries in Mexico, Nicaragua, and El Salvador.
} 


\section{American Journal of Sociology}

cruitment of women. ${ }^{8}$ Mason (1992) argues that women's aboveground organizing was met with extreme repression from the state, and this repression in turn pushed women to clandestine political mobilization for survival (see also Wickham-Crowley 1992). Regardless, both agree that women were mobilized as guerrillas because they first assumed new "masculine" roles such as household heads, paid laborers, and political activists, and yet maintained their "feminine" prioritization of child care, household survival, and social welfare. By extension, both suggest that women who were mothers, workers, and activists were rationally drawn to guerrilla movements. ${ }^{9}$ This argument parallels a large body of research that suggests women activists often legitimize their actions against the state by framing those actions as an integral component of their maternal responsibilities (Ferree and Mueller 2004). ${ }^{10}$

Recently, Kampwirth (2002) enhanced our understanding of women's guerrilla mobilization with individual-level interview data. Like previous studies, she finds that large-scale structural changes and international feminism generated new forms of women's activism. She expands on

${ }^{8}$ Revolutionary leaders were moving from a Guevara-inspired "foquismo" ideology, where a small group of revolutionaries was sufficient to inspire mass rebellion and rapid overthrow of the ruling regime, to a more Maoist understanding of a "prolonged people's war," where the support of the oppressed population over many years was necessary for the gradual wearing away of a long-oppressive regime. Reif-Lobao (1986) also argued in her earlier work that guerrilla groups conscientiously fostered women's participation by directly addressing women's issues through their internal organizational structures. Specifically, they worked toward abolishing the sexual division of labor, and they provided child and health care for guerrilla participants. This contention is dropped in her later article (Reif-Lobao 1998), however, likely in response to works like Murguialday (1996), Murguialday, Olivera, and Vásquez (1997), and Vázquez et al. (1996), which suggest that guerrilla camps, contrary to the early egalitarian rhetoric espoused by movement leaders, were in reality highly sexist in their division of labor and rules about sexual practices.

${ }^{9}$ Vázquez et al. also suggests that motherhood may be a mobilizer, as mothers sometimes followed their older sons and daughters into guerrilla activism (Vázquez et al. 1996, pp. 108-9).

${ }^{10}$ Motherhood often serves as both a collective identity and a collective action frame for women who participate in social and revolutionary movements (Molyneux 1985; Ferree and Mueller 2004). As a collective identity, motherhood allows women to develop a sense of "we-ness" with other women, even across political lines (Bayard de Volo 2001). As a collective action frame, mobilizing as mothers is not only strategically effective, but it also provides women some initial protection against state-sponsored violence. See, for example, Bouvard's (2002) discussion of "revolutionizing motherhood" in the Plaza de Mayo in Argentina, Naples's (1998) study of "activist mothering" in the U.S. war on poverty, and Noonan's (1995) analysis of women's anti-Pinochet protesting in Chile. Neuhouser (1995) found that the gendered division of labor shaped both strategies and outcomes in social movements in a Brazilian squatter community. Bayard de Volo (2001) provides a particularly nuanced discussion of the complex relationship between revolution and motherhood. 


\section{Women's Mobilization}

previous studies by arguing that family activism networks and newly emerging political and religious organizations were the agents of these new peaceful mobilizations. These new mobilizations were then specifically targeted by state repression, and state repression was the catalyst forcing peaceful activists into clandestine guerrilla organizations. Kampwirth also analyzes the importance of biographical barriers to participation and finds that mothers were less likely to join revolutionary movements than nonmothers. This contradicts earlier studies that find that women household heads constituted the "typical" guerrilla (Mason 1992; Reif-Lobao 1986; see also Vázquez et al. 1996).

Kampwirth's analysis of women's guerrilla participation suggests that the mobilization path that women follow to guerrilla camps is initially very similar to the mobilization path that most participants follow in any type of social movement. Participation-supporting network ties intersect with high levels of biographical availability and result in women's participation in peaceful political organizations. However, when government repression targets peaceful activists, these activists are then forced into clandestine armed combat (Kampwirth 2002; see also Mason 1992). Borrowing from this analysis, I add the effects of state-sponsored repression to the heuristic mobilization equation above and suggest that theories of women's guerrilla mobilization can be modeled as follows:

net influence of all networks -

the net influence of all biographical barriers $=$

the probability of movement activism,

and then

$$
\begin{gathered}
\text { movement activism }+ \text { state-sponsored repression }= \\
\text { guerrilla activism, }
\end{gathered}
$$

where, as in the earlier equation, networks are considered indispensable, and biographical barriers surmountable.

\section{PUTTING THEORY INTO PRACTICE}

Existing theory, as modeled in the above equations, allows for the possibility that different processes may lead different individuals to the same mobilization outcome. One type of network might matter for some individuals but not for others, some networks might be important at one point in a person's life but not at another, or some networks might affect mobilization only in particular combinations. Nevertheless, micromobilization researchers in practice generally seek the one pattern that most 


\section{American Journal of Sociology}

closely approximates the mobilization experience of all individuals. I argue that this search for the "typical" path to activism erroneously imposes uniform explanations on what is in reality an integrative, conjunctural, and varied mobilization process.

The case of women's guerrilla mobilization illustrates the necessity of identifying the multiple paths people follow to mobilization. Conventional explanations of women's guerrilla activism do not take into account the different ways that social networks, biographical characteristics, and situational contexts may interact. For example, scholars identify repression as important for women's guerrilla mobilization, but they fail to account for how the context of repression changes over the course of the movement, or how repression affects individuals differently based on their individuallevel biographies and network memberships.

Findings of uniformity in women's guerrilla mobilization, like findings of uniformity in other studies of mobilization, may be a product of the data employed. Researchers have studied only guerrillas; they have not gathered data that allow for comparisons with their nonguerrilla counterparts. ${ }^{11}$ Moreover, the guerrillas chosen for investigation have been selected almost exclusively from an elite subset of guerrillas: urban, middle-to-upper class, educated, and active in present-day movement organizations (Kampwirth 2002; Kriger 1992; Vázquez et al. 1996). Other research (Byrne 1996, p. 35; McClintock 1998, pp. 266-67; Paige 1997, p. 379, n. 49), as well as my own interviews, indicate that most women in FMLN camps were poor, uneducated, and from rural areas, and that nearly half did not remain active in civil society after the war was over. The experiences of the majority-who may have experienced entirely different paths to guerrilla mobilization-have been largely ignored.

In the following analysis, I use the case of women guerrillas in $\mathrm{El}$ Salvador to develop a new approach to micromobilization that allows for multiple, conjunctural paths to participation. I do so by employing better data and analyzing the dynamic interaction of network-based identities, biographical barriers, and situational contexts for each respondent. I find that Salvadoran women followed three distinct paths to guerrilla activism: I call them politicized guerrillas, reluctant guerrillas, and recruited guerrillas.

\footnotetext{
${ }^{11}$ Nearly all social movement researchers only study movement activists (and not nonactivists) and thus are guilty of sampling on the dependent variable. Notable exceptions include McAdam (1992), McAdam and Paulsen (1993), and Nepstad and Smith (1999).
} 
Women's Mobilization

DATA

The data for this study are interviews conducted between September 2001 and May 2002 with 82 rural Salvadoran women. ${ }^{12}$ To ensure a representative group of both guerrilla and nonguerrilla women for interviews, I first selected six villages from three different municipios that were included on a United Nations list of the 25 municipios most violently disputed during the 12-year civil war (see fig. 1). A municipio is similar to a U.S. county or parish in that it is a politically bounded geographic region that incorporates a number of smaller villages. The six villages were chosen to represent all five ideological branches of the FMLN and three distinct geographical regions. They range in size from 300 to 1,000 inhabitants.

I hired assistants from each community to administer a survey of all households in each village (or a random subset of households in the two largest villages). The short survey asked how many adults lived in each home, what their ages were, and whether or not any of them lived and worked in the guerrilla camps during the civil war. I used the survey results to select 14 women, seven guerrillas and seven nonguerrillas, from each community to interview. The guerrillas were selected at random, and the nonguerrillas were selected to match the ages of the chosen guerrillas as closely as possible. My resulting group of respondents is highly representative of the full population of the six villages in terms of age and participation distributions (details available upon request). Only one of the initially identified individuals (1.2\%) refused to be interviewed; she was replaced with another woman of the same age and participation status who in turn complied. ${ }^{13}$ Interviews with four former high-ranking military officials within the FMLN guerrilla army provide additional information about recruitment practices. ${ }^{14}$

\footnotetext{
${ }^{12}$ I focus on women in part because gender has been shown to affect microlevel mobilization patterns in high-risk social movements (Irons 1998; McAdam 1992); focusing exclusively on women therefore allows me to create a baseline model capturing heterogeneity among activists. Moreover, the atypical nature of women's guerrilla participation has generated more academic inquiry into micromobilization processes than has the participation of men, and thus provides a broader theoretical base from which to build my model.

${ }^{13}$ Interviewing 14 women in each of six communities initially generated 84 interviews. However, two of the original 84 interviews were dropped from this analysis, resulting in my reported $N$ of 82 . The first woman was 19 at the time of the interview, which would have made her only eight years old when the peace accords were signed in 1992 , and too young to remember well the events of the 1980s. The second was dropped because a technical glitch resulted in an unrecorded interview.

${ }^{14}$ Of the four, two were women, two were men, and each represented a different ideological branch of the FMLN. These interviews were conducted by an assistant with ties to the FMLN, recorded, and transcribed in their entirety.
} 


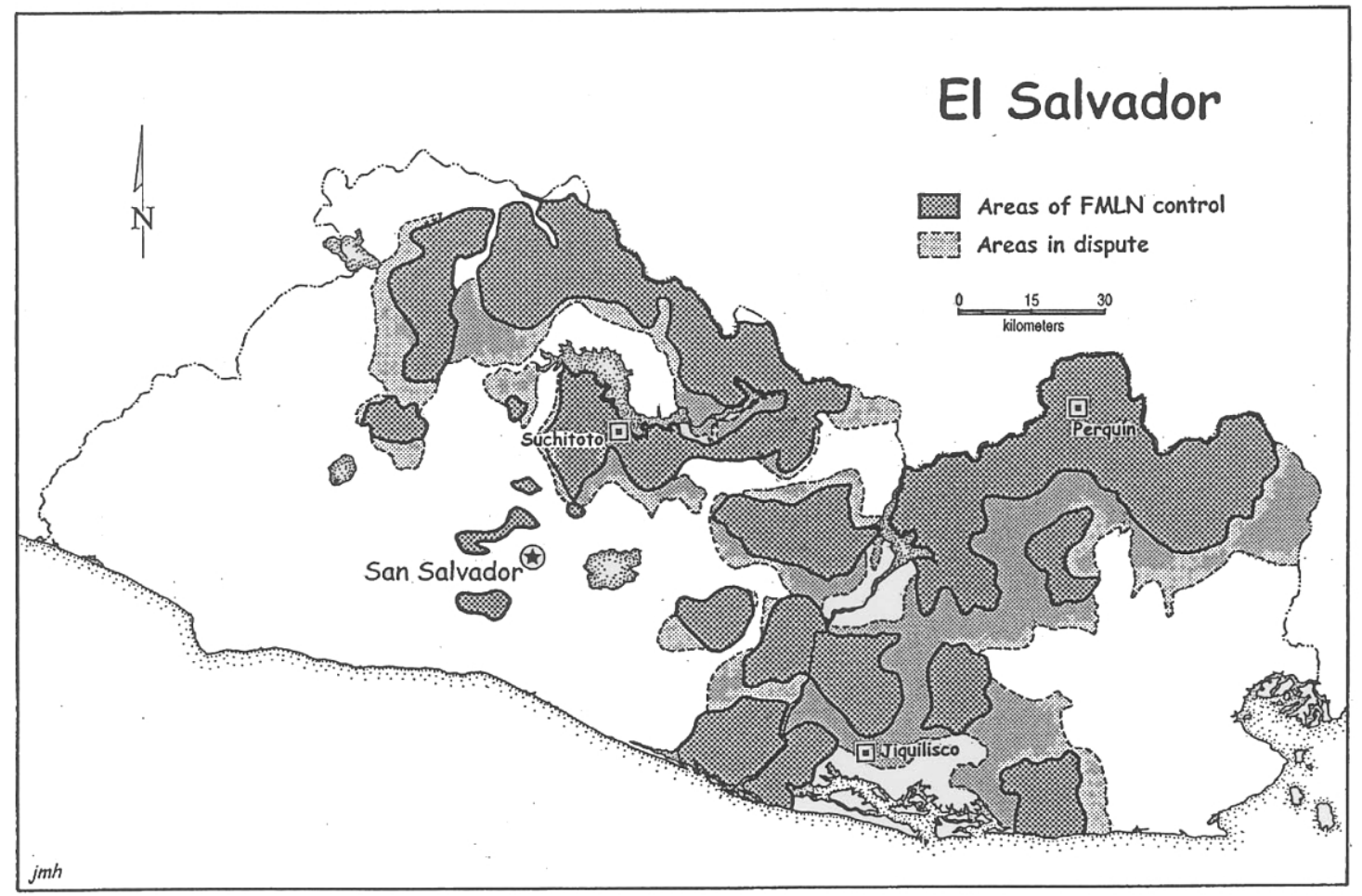

FIg. 1.-Research locations 


\section{Women's Mobilization}

To gain respondents' trust prior to conducting the interviews, I lived in each community for a period of one to two months, usually in the home of a female council member. I actively took part in daily activities such as washing clothes, hauling water, harvesting corn, and making tortillas. Salvadorans responded very positively to this research project. In fact, I had more difficulty explaining to nonselected individuals why I was not going to interview them than I had convincing selected respondents to participate. Respondents were not compensated for their participation; by contrast, many insisted on preparing and sharing a meal with me after our interview was complete. Interviews were usually conducted on the front patio of the respondent's home, distanced from other adults in the household. The shortest interviews lasted about 90 minutes and the longest about eight hours over two separate afternoons. Interview questions asked about basic demographic information; opinions about politics, community, gender, and society; present-day activities; and histories of wartime experiences. All interviews were conducted in Spanish and were recorded and later transcribed. I conducted $80 \%$ of the interviews myself, and trained assistants conducted $20 \%$.

This study, like most analyses of past social processes in developing nations, depends on people's recollections about prior experiences. ${ }^{15} \mathrm{An}$ alyzing retrospective data requires some caution because present-day reports of the past can be malleable (Auyero 1999; Schwartz 1997; Sudman, Bradburn, and Schwarz 1996; Zerubavel 1996). ${ }^{16}$ In addition to basic recall difficulties, respondents' accounts of the past may be influenced by their present-day identities, especially given that movement participation itself may cause identity shifts (Calhoun 1994; Larana, Johnston, and Gusfield 1994).

To address the first concern, accuracy of recall, I structured my questionnaire around past events rather than past attitudes because memories of events are more reliable (Markus 1986; Schacter 1996). For example, I asked each respondent where she lived during the war, who she lived with, whether she left her home for a refugee camp, and so forth. Research

\footnotetext{
${ }^{15}$ Most grassroots participants in the Salvadoran revolutionary movement were illiterate or only slightly literate and left few written records during the war. A few government agencies and researchers conducted surveys of rural Salvadorans during the 1980s, but respondents were often unwilling to provide personal information to unknown questioners during this politically violent time (Wood 2003, p. 32).

${ }^{16}$ Nevertheless, many sociological fields concur that retrospective reports of behavior and events generate valid results when used appropriately. See, for example, studies of immigration (Massey and Zenteno 2000), life course (Scott and Alwin 1998), organizations (Miller, Cardinal, and Glick 1997), and mobility (Blau and Duncan 1967). In El Salvador, Elisabeth Wood (2003) provides a nuanced discussion of how retrospective data allows for new insights into campesinos' participation in land seizures and agricultural cooperatives.
} 


\section{American Journal of Sociology}

shows that more salient, less repetitive events are remembered with particular accuracy (Scott and Alwin 1998, p. 114; Becket et al. 2000), and that highly intense or violent events (such as those reported by my respondents) are especially well remembered in both the short and long term (Bradley 1994; Schacter 1996; Wagenaar and Groeneweg 1990; Witvliet 1997; see also Wood 2003). Once I had developed an event-based understanding of each woman's situation before and during the war, I followed with more general questions intended to elicit narrative accounts of her mobilization experience (What is your earliest memory of the war? How is it that you ended up in a guerrilla camp?). ${ }^{17}$ Mixing the recall of events with more open-ended narrative questions proved effective; women consistently cited one of three general motivations to justify their participation in the FMLN guerrilla army, and women in each motive category were distinguished by a unique set of objective experiences. The fact that more subjective reports of motivations dovetailed with previously stated and highly objective reports of major life events suggests that particular experiences and relationships were indeed more likely to promote guerrilla mobilization than others. ${ }^{18}$

To address the second concern, the issue of causal order, I hypothesized which present-day identities and experiences might affect my respondents' reports of past motivations for participation. For example, I anticipated that women who continue to associate with the FMLN, which is now a political party, might remember positive reasons for mobilization, while women who express disillusionment with the present-day FMLN may explain past participation as forced. To investigate this possibility, I coded my respondents according to a number of measures of their present-day views of the FMLN (who received material benefits because of their guerrilla participation, who votes for the FMLN, who identifies the FMLN as their preferred party, who reports "growing personally" because

\footnotetext{
${ }^{17}$ A narrative style is most compatible with how autobiographical knowledge is structured (Belli, Shay, and Stafford 2001; Brown and Schopflocher 1998).

${ }^{18}$ Retrospective data about the occurrence of past events are generally considered reliable and valid. However, the details and dates surrounding those events are sometimes less easily remembered. I put dates on each reported biographical event by employing my knowledge of local history and other events in the respondents' lives. For example, if the respondent recalled fleeing to a refugee camp after her village was massacred, but could not recall the exact year, then I used official accounts of the massacre to put an exact date on her escape. If the respondent was unsure what years she participated in a particular organization, I asked if she remembered bringing her children with her to the meetings, and which children were there. Then I could use the age of the children to estimate her years of attendance. Asking if events occurred before or after a particular massacre, the paving of the community road, the arrival of electricity, the killing of Archbishop Romero, etc., also helped put a timeline on each individual's biography.
} 


\section{Women's Mobilization}

of their wartime participation, who says their life is better because of the war). I then examined the correlations between these present-day measures and my three mobilization paths (discussed below). No significant correlations were found, suggesting that the mobilization patterns I identify cannot be explained by present-day patterns in my respondents' feelings toward the FMLN.

I repeated this search for meaningful correlations by analyzing my respondents' communities of origin, civil statuses, more general political beliefs, measures of gendered identities, and present-day political and community activities. Again, none of these present-day measures was significantly correlated with any of the identified mobilization paths. Neither did I find any significant relationship between reported mobilization and the amount of time that each respondent actually lived and worked in guerrilla camps. In total, I found one significant correlation. Women who mobilized as politicized guerrillas are more likely to be present-day community leaders (Spearman's $\rho=.421$ ), suggesting that the presentday identity of "leader" might influence the way that mobilization is remembered. ${ }^{19}$ (I discuss the theoretical and empirical ramifications of this possibility in n. 30 in the conclusion.) In general, however, women's mobilization narratives do not appear to be influenced in patterned ways by present-day social contexts or wartime experiences.

\section{VARIABLES}

The dependent variable, wartime participation, identifies three levels of activism in relationship to the FMLN: guerrillas, collaborators, and nonparticipants. These are described in table 1 . In my sample, 38 women are guerrillas, 12 are collaborators, and 32 are nonparticipants.

The independent variables measure each woman's objective conditions of mobilization. They include three measures of network ties prior to mobilization (previous organizational involvement, family ties with guerrillas, living in a refugee camp or repopulated community), three measures of biographical availability (motherhood, family completeness, age at mobilization), and one measure of changing situational context (time of mobilization).

Networks.-The literature highlights two networks as crucial for mobilizing individuals into guerrilla armies: family ties with guerrillas and relational ties generated through membership in organizations working

${ }^{19}$ Of course, the causal arrow could also arguably point the other direction; women who mobilized politically into the guerrillas in the past may be more likely to become community leaders in the present. If this were the case, it would do little to undermine my classification of mobilization motives into these three patterns. 
TABLE 1

SPECIFYING THE VARIABLES

\begin{tabular}{|c|c|}
\hline Variable & Specification \\
\hline \multicolumn{2}{|c|}{ Dependent variable (wartime participation): } \\
\hline Guerrilla & $\begin{array}{l}\text { Respondent lived and worked in or alongside an } \\
\text { FMLN guerrilla camp as a primary, permanent } \\
\text { residence, usually for a period of years, but for } \\
\text { at least six months. }\end{array}$ \\
\hline Collaborator & $\begin{array}{l}\text { Respondent maintained a household as a primary } \\
\text { residence, but held a formally defined role of } \\
\text { support for the guerrilla camps. Support roles in- } \\
\text { clude but are not limited to making frequent } \\
\text { trips to camps to deliver supplies and intelli- } \\
\text { gence information; assisting with intelligence } \\
\text { gathering, weapons preparation, or sabotage ef- } \\
\text { forts; or allowing home to be used as guerrilla } \\
\text { "safe house." Collaboration is highly dangerous } \\
\text { work, but does not require a sacrifice of home } \\
\text { and family. }\end{array}$ \\
\hline Nonparticipant & $\begin{array}{l}\text { Respondent maintained a household as a primary } \\
\text { residence and did not hold any formal positions } \\
\text { of support for the guerrilla. She may have sym- } \\
\text { pathized with the guerrilla movement or helped } \\
\text { on occasion, but this relationship was never } \\
\text { formalized. }\end{array}$ \\
\hline \multicolumn{2}{|c|}{$\begin{array}{l}\text { Independent variables (factors motivating or inhibiting guerrilla participation): } \\
\text { Network ties: }\end{array}$} \\
\hline $\begin{array}{l}\text { Previous organizational } \\
\text { involvement }\end{array}$ & $\begin{array}{l}\text { The respondent reported participation in a political } \\
\text { or religious organization that advocated reforms } \\
\text { similar to those advocated by the FMLN guer- } \\
\text { rilla organization. For guerrillas, the organiza- } \\
\text { tional involvement must predate guerrilla activ- } \\
\text { ism. For nonguerrillas, any organizational } \\
\text { involvement prior to or during the war is } \\
\text { included. }\end{array}$ \\
\hline Family ties & $\begin{array}{l}\text { The respondent had a mother, father, sibling, part- } \\
\text { ner, or child who was active in the FMLN as a } \\
\text { collaborator or guerrilla. For guerrillas, the fam- } \\
\text { ily participation must predate or begin simulta- } \\
\text { neously with her activism. For nonguerrillas, any } \\
\text { family participation prior to or during the war is } \\
\text { included. }\end{array}$ \\
\hline $\begin{array}{l}\text { Refugee/repopulated } \\
\text { community }\end{array}$ & $\begin{array}{l}\text { The respondent lived in a refugee camp or a repo- } \\
\text { pulated community. Guerrillas must have lived } \\
\text { in the refugee camp or repopulated community } \\
\text { at the moment of mobilization. Nonguerrillas } \\
\text { must have lived in a refugee camp or repopu- } \\
\text { lated community at some point during the war. }\end{array}$ \\
\hline
\end{tabular}




\section{Women's Mobilization}

TABLE 1 (Continued)

\begin{tabular}{|c|c|}
\hline Variable & Specification \\
\hline \multicolumn{2}{|l|}{ Biographical availability: } \\
\hline Motherhood & $\begin{array}{l}\text { For guerrillas, the respondent had children at the } \\
\text { moment of mobilization into the FMLN. For } \\
\text { nonguerrillas, the respondent had children prior } \\
\text { to or during the war. }\end{array}$ \\
\hline Family completeness & $\begin{array}{l}\text { For guerrillas, the respondent lived with both her } \\
\text { parents at the moment of mobilization into the } \\
\text { guerrillas, or if she had already left the home of } \\
\text { her parents, then the respondent's partner was } \\
\text { present in the home at the moment of mobiliza- } \\
\text { tion into the guerrillas. For nonguerrillas, the re- } \\
\text { spondent had a complete family during the en- } \\
\text { tire length of the war. }\end{array}$ \\
\hline Age at mobilization & $\begin{array}{l}\text { For guerrillas only: the respondent's age at the mo- } \\
\text { ment she was mobilized into the guerrilla army. }\end{array}$ \\
\hline \multicolumn{2}{|l|}{ Situational context: } \\
\hline Mobilization period & $\begin{array}{l}\text { For guerrillas only: the respondent's mobilization } \\
\text { into the FMLN either occurred early in the war } \\
(1980-83) \text { or late in the war (1985-91). }\end{array}$ \\
\hline
\end{tabular}

for social change (Dodson and O'Shaugnessy 1985; Kampwirth 2002; Vázquez et al. 1996; Wickham-Crowley 1992). To these, I add the experience of living in a refugee camp or a repopulated community. This has not been mentioned as a mobilizing factor for women guerrillas. However, given that 1.5 million rural Salvadorans, or $20 \%$ of the total Salvadoran population, were displaced from their homes by 1983 (Commission on the Truth 1993), and given the documented political organizing that occurred within refugee camps (Cagan and Cagan 1991; Vázquez 2000), this is an important area for investigation.

Biographical availability.-Young women with no children and a missing parent at home are expected to have the fewest barriers to participation (Kampwirth 2002; see also Vilas 1986). Children are barriers because their needs limit the work a woman may perform outside the home. Parents are barriers because they may prevent their children from joining the guerrillas. However, some scholars suggest that motherhood encourages women to mobilize because their position as caretaker of the family motivates them to create a better world for future generations (Reif-Lobao 1986, 1998; Mason 1992; Vázquez et al. 1996).

Mobilization period.-The pervasiveness of state-sponsored violence varied greatly during the civil war. In the early years (1980-83), repression was widespread and indiscriminate, and opportunities to escape the violence were few. The Salvadoran Armed Forces, in their attempts to 


\section{American Journal of Sociology}

squelch civilian support for the nascent FMLN guerrilla organization, adopted a "scorched earth" policy. This included indiscriminate massacres of rural peasants, air attacks on rural communities, burning homes and crops, and killing livestock. The number of civilian deaths in 1982 alone was estimated at nearly 6,000 , or three times the number of deaths among guerrilla combatants (Commission on the Truth 1993). In 1984, repression decreased momentarily in conjunction with talks of civilian elections and peace negotiations, but military activity on both sides increased again from 1985 to 1991. Unlike the earlier period of war, however, repression in the latter period was less prevalent and more discriminate. The government's scorched earth campaigns had been halted by international political pressure and the general ineffectiveness of the tactic, and international aid had provided civilians with a means to escape the violence; tens of thousands of rural Salvadorans were now living in refugee camps, mostly in Honduras, or were later moved to FMLN-sponsored "repopulated" communities well within guerrilla-controlled territory. ${ }^{20} \mathrm{I}$ operationalize this changing context of repression by determining whether a woman was mobilized early in the war (1980-83) or late in the war (1985-91). None of my respondents was mobilized in 1984, the year when peace briefly seemed possible. The measurement of all variables is given in table 1.

\section{THE CONVENTIONAL MODEL OF WOMEN'S GUERRILLA MOBILIZATION}

Scholars of women's guerrilla mobilizations find that women join rebel armies when they are biographically available, already active in organizations with similar goals and ideologies, have family members active in the revolutionary movement, and are forced to abandon their peaceful protest activities because of government-sponsored repression. Table 2 demonstrates the inability of this one pattern to explain most women's mobilization into guerrilla armies when a representative sample of both participants and nonparticipants is used. Similar numbers of guerrillas and nonguerrillas were mothers, were missing a parent or spouse, and had family members active in the movement. Neither did my added variable, living in a refugee camp, effectively distinguish between participants and nonparticipants. Only one of the presumed factors in guerrilla mo-

\footnotetext{
${ }^{20}$ In 1986, Salvadoran refugees in Honduran refugee camps successfully bargained with the Salvadoran government for repatriation rights and assistance. Over the next few years, they returned to El Salvador in groups and settled on abandoned land in guerrilla-controlled territory. These communities were generally highly sympathetic to the FMLN and somewhat protected from hostilities by their location.
} 


\section{Women's Mobilization}

TABLE 2

Bivariate Correlations (Spearman's $\rho$ ) Between Selected Mobilization Characteristics and Women's Guerrilla Participation

\begin{tabular}{|c|c|c|c|}
\hline & Guerrillas & Nonguerrillas & Spearman's $\rho$ \\
\hline \multicolumn{4}{|l|}{ Network ties: } \\
\hline Previous organizational involvement (\%) $\ldots$ & 39.5 & 15.9 & $.265 * *$ \\
\hline Family ties to guerrillas $(\%) \ldots \ldots \ldots \ldots \ldots$ & 81.6 & 81.8 & -.003 \\
\hline Refugee camp/repopulation (\%) & 42.1 & 59.1 & -.183 \\
\hline \multicolumn{4}{|l|}{ Biographical availability: } \\
\hline Motherhood (\%) & 31.6 & $48.5^{\mathrm{a}}$ & -.173 \\
\hline Family completeness $(\%)$ & 31.6 & 43.2 & -.129 \\
\hline Mean age at time of interview & 36.9 & 36.9 & \\
\hline Age range at time of interview $\ldots \ldots \ldots \ldots \ldots$ & $24-73$ & $23-66$ & \\
\hline Mean age at mobilization $\ldots \ldots \ldots \ldots \ldots \ldots \ldots$ & 19.2 & & \\
\hline Age range at mobilization & $7-60$ & & \\
\hline \multicolumn{4}{|l|}{ Situational context: } \\
\hline Early mobilization period $N$ & 20 & & \\
\hline bilization period $N$. & 18 & & \\
\hline Across period $N$. & 38 & 44 & \\
\hline \multicolumn{4}{|c|}{$\begin{array}{l}{ }^{a} \text { Eleven women gave birth between } 1981 \text { and } 1992 \text { and were therefore both mothers and nonmothers } \\
\text { during the war; these } 11 \text { were dropped from the motherhood analysis. Age is expressed in years. } N=82 \text {. } \\
* P<.05 \text {, one-tailed tests } \\
{ }^{* *} P<.01 \text {. }\end{array}$} \\
\hline \multicolumn{4}{|c|}{$\begin{array}{l}\text { bilization-previous organizational membership-appears significant; } \\
\text { more guerrillas than nonguerrillas were previously involved in political } \\
\text { organizations. Regardless, over } 60 \% \text { of the women who became guerrillas } \\
\text { did not have prior organizational involvement, indicating that many } \\
\text { women were mobilized by other processes. }\end{array}$} \\
\hline
\end{tabular}

\section{A NEW APPROACH: CAPTURING VARIATION IN MOBILIZATION}

The previous analysis demonstrates the inability of conventional "onepattern" methods to explain the varied processes by which mobilization actually occurs. I do not doubt that the networks and barriers identified in previous research are central mobilizing factors for women guerrillas. Rather, I argue that the way these networks and barriers interact for individual women and within a particular situational context is the key. I further argue that because the variation in mobilization processes is patterned, scholars can identify multiple paths to activism while still prioritizing parsimonious explanations. Through analysis of my respondents' narratives, I found three clear mobilization patterns, which I have labeled politicized guerrillas, reluctant guerrillas, and recruited guerrillas. Next, I grouped women according to these three patterns, and I documented whether specific combinations of objective factors clustered together 


\section{American Journal of Sociology}

within each category. I also analyzed qualitatively how women discussed these objective factors within their mobilization narratives. I conclude that distinct combinations of objective factors consistently resulted in each particular mobilization narrative. I review these analyses below.

\section{Politicized Guerrillas}

[I went to the guerrilla camp] to change this country. Because the government was corrupt and we had to fight.- Pati $^{21}$

Politicized guerrillas were pulled into guerrilla participation by their strongly held beliefs in the political causes of the FMLN. Of the three mobilization patterns, this is the closest to the "typical" route to guerrilla activism proposed in the established literature. Politicized guerrillas developed a salient participation identity through their involvement in political organizations and then followed guerrilla recruiters to the FMLN camps. Surprisingly, only seven of the 38 guerrilla women in this study cite political reasons as their primary motivation for participation. ${ }^{22}$

Table 3 reviews the objective conditions of mobilization for politicized guerrillas, with " $\mathrm{X}$ " indicating the presence of a variable. Looking first at the networks, each politicized guerrilla was previously involved in a political or religious organization that facilitated their recruitment into the FMLN.

So when the women of AMES (Association of Salvadoran Women) held their meetings, I went. And when they said that whoever wanted to go to the guerrilla camps should raise their hand, well, I said me too. So fourteen of us, young girls, left together. . . . We said "we're going to go!" They told us that they were going to have a party to swear us in, so they swore us in and put the bandana of the FMLN around our left arm, since we've always been people of the left, they put the bandana here . . . then they sent us off for some short training courses.-Alicia

We began to work in this ORMUSA, this group of women that worked in the communities raising crops, talking to the people, [finding out] what they needed, if they were sick, healthy. I was part of the board of directors of ORMUSA. . . . We worked a while and then we started coordinating with the people who worked in the clandestine. . . . Once you're involved in this it is difficult to leave.-Zoila

${ }^{21}$ All names are pseudonyms, and all translations are my own.

${ }^{22}$ The small number of guerrillas in this category may be attributed to their early entry into the war and their dedication to the causes of the war. It may be that politicized guerrillas were in the war for longer periods of time and took part in more dangerous types of guerrilla activities than women in other categories, so fewer politicized guerrillas may have survived the war to be included in my study. 


\section{Women's Mobilization}

Politicized guerrillas were also embedded in family networks that supported guerrilla activism. Family ties to revolutionary activists are not specific to politicized guerrillas, but the qualitative data suggest that the depth of political activism of these family members is exceptional. For example, Alicia's father was a founding member of FECCAS (Christian Federation of Salvadoran Peasants), one of the largest and most important of all peasant political groups. Estela's parents joined forces with the Catholic Church to demand and win restitution when the government flooded the land on which they worked for wages. Vilma, Zoila, and Pati participated in political or religious organizations with other members of their families.

FMLN commanders also indicate that organizational and family ties were key vehicles for recruiting guerrillas, especially during the early period of the war. Designated recruiters targeted existing organizations as a means of appropriating networks already sympathetic to the FMLN cause, as well as to ensure that the new recruits could be trusted not to reveal the identity of clandestine FMLN sympathizers to the Salvadoran Armed Forces. New recruits were then sent through a political education program designed with easily accessible language for poorly educated rural peasants. "At the very least we wanted to make sure they were clear on the most basic elements of why we were fighting the war," stated one commander.

The biographical characteristics of politicized guerrillas are not as central to mobilization as the network variables. The only consistent biography is complete family. Six of the seven report having lived with both parents or with their spouse at the time of mobilization. This is unexpected; complete families are hypothesized as barriers to participation. The depth of family members' participation in political activity (see above) may account for this seeming contradiction. The other biographical measures are inconsistent. Most politicized guerrillas mobilized in their midto-late teens, but some mobilized much later in life. Moreover, five politicized guerrillas were not mothers at the time of mobilization, but two overcame the barrier of motherhood to join the guerrilla army. Zoila joined after her two children had grown and left home (one had joined the FMLN). Pati joined with her husband and their two children (ages approximately 7 and 9). In her interview, she states that she wanted her children to learn of the necessity of social struggle. These two cases give tentative support to previous findings that strong participation identities may overcome biographical barriers to participation.

While biographical factors vary, the situational context of politicized guerrillas is similar; most mobilized in the early 1980s when repression 
TABLE 3

Objective Conditions of Mobilization for Women Guerrillas by Mobilization Category

\begin{tabular}{|c|c|c|c|c|c|c|c|}
\hline Respondent & $\begin{array}{c}\text { Age at } \\
\text { Mobilization }\end{array}$ & $\begin{array}{c}\text { Year of } \\
\text { Mobilization }\end{array}$ & Motherhood & $\begin{array}{c}\text { Complete } \\
\text { Family }\end{array}$ & $\begin{array}{c}\text { Refugee } \\
\text { Camp }\end{array}$ & $\begin{array}{c}\text { Previous } \\
\text { Organizational } \\
\text { Involvement }\end{array}$ & $\begin{array}{c}\text { Family } \\
\text { Members } \\
\text { Active }\end{array}$ \\
\hline \multicolumn{8}{|l|}{ Politicized guerrillas: } \\
\hline Vilma $\ldots \ldots \ldots \ldots$ & 16 & 1981 & & $\mathrm{X}$ & & $\mathrm{X}$ & $\mathrm{X}$ \\
\hline Alicia ............. & 16 & 1981 & & $\mathrm{X}$ & & $\mathrm{X}$ & $\mathrm{X}$ \\
\hline Estela $\ldots \ldots \ldots \ldots$ & 16 & 1980 & & $\mathrm{X}$ & & $\mathrm{X}$ & $\mathrm{X}$ \\
\hline Pati $\ldots \ldots \ldots \ldots \ldots$ & 26 & 1980 & $\mathrm{X}$ & $\mathrm{X}$ & & $\mathrm{X}$ & $\mathrm{X}$ \\
\hline Zoila $\ldots \ldots \ldots \ldots$ & 42 & 1989 & $\mathrm{X}$ & $\mathrm{X}$ & & $\mathrm{X}$ & $\mathrm{X}$ \\
\hline Gregoria $\ldots . . . . . .$. & 13 & 1980 & & $\mathrm{X}$ & & $\mathrm{X}$ & \\
\hline Gloria ............. & 16 & 1980 & & & & $\mathrm{X}$ & \\
\hline \multicolumn{8}{|l|}{ Reluctant guerrillas: } \\
\hline Julia $\ldots \ldots \ldots \ldots \ldots$ & 7 & 1976 & & & & & $\mathrm{X}$ \\
\hline Claudia $\ldots \ldots \ldots \ldots$ & 15 & 1983 & & & & & $\mathrm{X}$ \\
\hline Maria $\ldots \ldots \ldots \ldots$ & 13 & 1983 & & & & & $\mathrm{X}$ \\
\hline Yenifer $\ldots \ldots \ldots \ldots$ & 11 & 1981 & & & & $\mathrm{X}$ & $\mathrm{X}$ \\
\hline Blanca ............ & 17 & 1983 & & $\mathrm{X}$ & & & $\mathrm{X}$ \\
\hline Juana $\ldots . . . . . . . .$. & 60 & 1989 & $\mathrm{X}$ & & & $\mathrm{X}$ & $\mathrm{X}$ \\
\hline Gladis ............ & 35 & 1980 & $\mathrm{X}$ & & & $\mathrm{X}$ & $\mathrm{X}$ \\
\hline Lulu .............. & 34 & 1981 & $\mathrm{X}$ & & & $\mathrm{X}$ & $\mathrm{X}$ \\
\hline Angela $\ldots . . . \ldots .$. & 24 & 1981 & $\mathrm{X}$ & & & $\mathrm{X}$ & $\mathrm{X}$ \\
\hline Margarita ......... & 29 & 1983 & $\mathrm{X}$ & $\mathrm{X}$ & & $\mathrm{X}$ & $\mathrm{X}$ \\
\hline Mirna ............ & 23 & 1982 & $\mathrm{X}$ & & & & $\mathrm{X}$ \\
\hline Rosmaria ......... & 28 & 1981 & $\mathrm{X}$ & & & & $\mathrm{X}$ \\
\hline Yaniris $\ldots . . . \ldots . .$. & 21 & 1980 & $\mathrm{X}$ & & & & \\
\hline Andrea $\ldots . . . \ldots . .$. & 43 & 1983 & $\mathrm{X}$ & $\mathrm{X}$ & & & \\
\hline
\end{tabular}




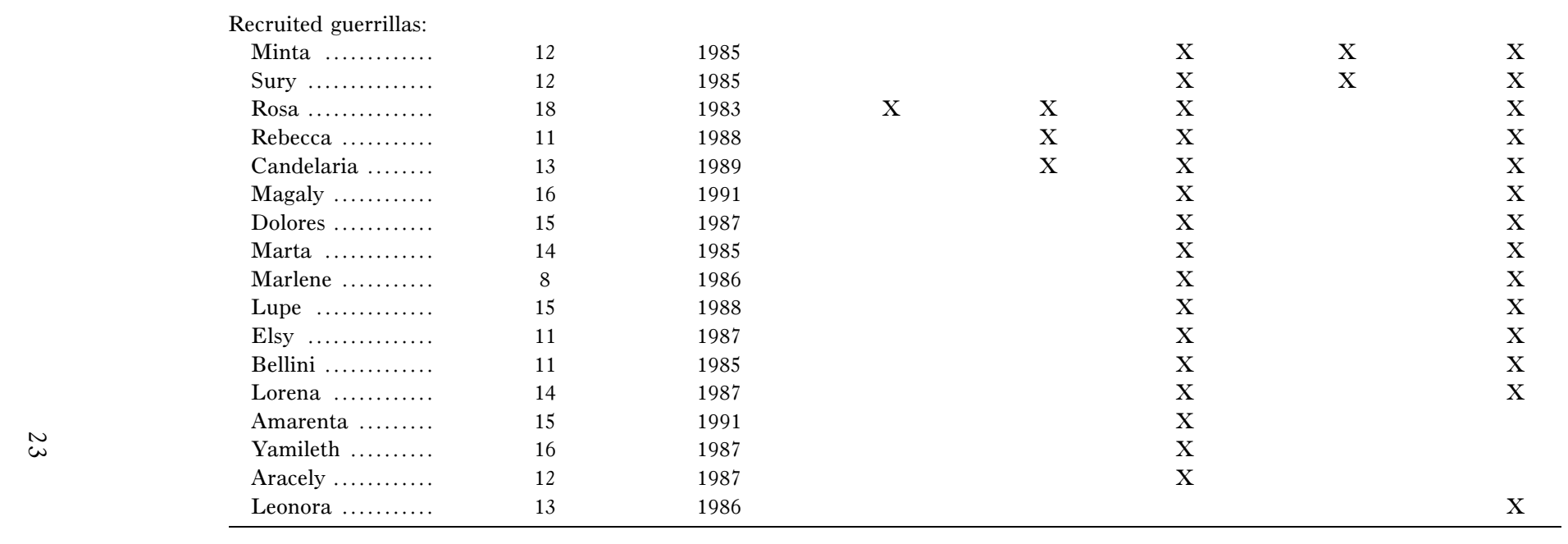




\section{American Journal of Sociology}

was beginning to escalate. ${ }^{23}$ Several politicized guerrillas mentioned the general hostile environment as a motivator for guerrilla participation, but none report being targeted for repression because of their organizational involvement. This differs from previous studies that suggest government repression forced peaceful activists to take their politics underground.

In sum, politicized guerrillas were pulled into the FMLN early in the war because they were already embedded in organizational and familial networks of activism. The catalyst moving peaceful activists into guerrilla camps appears to be that these networks were targeted by guerrilla recruiters, and not by state repression. In several instances, the salience of the participation identity generated through these networks overcame the potential biographical barriers of motherhood and older age.

\section{Reluctant Guerrillas}

In this war, you don't get involved because you want to, but because you have to. Because if you don't, they kill you. Even though you didn't know anything about the war.-Julia

The 14 women classified as reluctant guerrillas were pushed into the guerrilla camps because a crisis left them with no other options. Their stated motivations focus on government repression, a need to flee hostilities, and a lack of resources for escaping to any other safe location.

It wasn't that I wanted to go to the mountain, but like they say, el amor a la vida es grande [the love of life is strong]. And even though you might be suffering, if you're alive ....-Lulu

Most crises that motivated the reluctant guerrillas to mobilize with the FMLN involved generalized violence against entire villages:

I remember one time they (presumably members of the revolutionary movement) came and showed us a "butido." Butido is what they called this hole they had made, under the ground. Yes. So, they had a big meeting . . . we went, because this was a precaution for when the armed forces arrived, they said that we would get in there, because this thing had a long ventilation shaft, but the next day I was captured with my mom. . . . And so we didn't have the opportunity . . . well, nobody had the opportunity, to go to that place and hide and be free. That was when, this (military) operation was when all the people in this place died.-Yenifer

${ }^{23}$ Zoila is the only politicized guerrilla mobilized late in the war. Nevertheless, she had been an active guerrilla collaborator and community leader since 1983 and made the move into the guerrilla camps in 1989 immediately prior to the FMLN "final offensive." 


\section{Women's Mobilization}

They warned . . . they told us . . . one hears things . . . the plane, circling and circling, we knew that something was coming by land, and they told us, let's go, because the enemy is coming near, they said . . . before the massacre. They got us out . . . and the rest of the people they weren't able to get out because (the lake) was full of "lettuce" (green leafy water plants that prohibit passage by boat). . . . That's why they were left behind.Andrea

Nevertheless, two cases involved violence targeted specifically against the respondent and her family:

When I realized that my spouse was involved [with the guerrillas], because I didn't know before, was when they started "putting the finger on us" [identifying us as subversives], and then the army would arrive and interrogate us. The people knew that I was married and that he was my husband, and so every day the soldiers would arrive and I would tell them the same thing. And then they began to interrogate my father, and the next day my father told me that we should get out of there, so we waited for the clean clothes to dry and the next day we left there because they were going to kill us. A letter from my husband arrived saying that they were going to kill us, so I left with my little suitcase and my child. . . . My husband told me that I should go to the camp, because there we could have a separate life, where the army would not find us.-Mirna

The objective conditions shared by reluctant guerrillas are documented in table 3. Network ties are inconsistent among women who cite a crisis as their motivation for mobilization. Nearly half were involved in previous organizational activities, but none invoked these activities when telling of their decision to move to the guerrilla camp. Moreover, most of those reporting previous organizational activity (five out of six) were mothers, suggesting that these politically active women were perhaps inhibited from earlier guerrilla activity because of the biographical barrier of young children; they only entered the guerrilla camp when a crisis made it unavoidable. ${ }^{24}$ Nearly all reluctant guerrillas had family members working with the FMLN, and at least six of them went to the guerrilla camps at the moment of crisis because they were seeking family members already living there. Network ties therefore may not have motivated activism, but they may have provided a resource for escaping government repression into an FMLN camp.

Biographically, reluctant guerrillas are diverse. Crises, it seems, pushed all biographical categories of women (older and younger, mothers and

${ }^{24}$ None of the politically involved reluctant guerrillas suggested that they were specifically targeted by repression because of their activities as suggested in the current literature. Rather, they were members of villages that came under indiscriminate state violence. 


\section{American Journal of Sociology}

nonmothers) into the guerrilla camps. Nevertheless, the qualitative data indicate that young, childless reluctant guerrillas had additional difficulty escaping guerrilla mobilization in times of crisis. Yenifer (quoted above) was captured by the Salvadoran Armed Forces when her village was attacked, and she and her mother were forced to cook and do laundry as they traveled with the soldiers for 30 days. When the military operation ended and the soldiers withdrew from the region, they were set free, but they feared remaining in their decimated and abandoned community. The FMLN offered her mother and sister escort to the refugee camp, but Yenifer stayed behind in the guerrilla camps. When I asked why she, too, did not go to the refugee camp, she responded:

Yenifer: Because I was already about 11 years old and I couldn't go to the refugee camp because the Honduran soldiers would rape young girls. Interviewer: But your sister went, didn't she?

Yenifer: Yes, but she already had a child, my niece, in her arms. The baby was about 5 months old, something like that.

Interviewer: But why a guerrilla camp, at 11 years old?

Yenifer: Because we couldn't just ask to live. If it wasn't the guerrillas, it was the Armed Forces. Because you see, here, if I stay, the Armed Forces kill me. If I go where the Armed Forces are in control, the guerrillas will kill me. That's why I went. What's more, the Armed Forces had killed nearly all our family, so I certainly couldn't follow them.

Interviewer: And you thought that it was safer to join the guerrillas than to go to a refugee camp?

Yenifer: Yes! [with conviction] Since the very same guerrillas had taken my mother out of the house and to the refugee camp, since she could no longer live there, then I had to go to live with the guerrilla combatants. I couldn't stay in the house or in any other area that wasn't the guerrillas. Interviewer: Who said that the Honduran soldiers would rape young girls? Yenifer: Everyone said so.

The case of Blanca represents the only young reluctant guerrilla who lived with both her parents at the time of crisis. She is also the only reluctant guerrilla who lived near the Honduran border at the time of crisis. These resources of family ties and proximity to a refugee camp nearly allowed her to mediate the crisis of villagewide displacement by fleeing to a Honduran refugee camp under FMLN escort. ${ }^{25}$ When she arrived at the Honduran border, however, the FMLN escorts singled Blanca out and told her to return to the war zone with them:

Blanca: Because they didn't let us in, we had to stay here; they only took

\footnotetext{
${ }^{25}$ The FMLN frequently escorted civilian populations, both supporters and nonsupporters, out of the conflict zones and to the Honduran border where the civilians could then make a run for the nearby refugee camp.
} 


\section{Women's Mobilization}

the little kids, up to 9 or 10 years old. Those who were already 14 or 15 they left here.

Interviewer: Who didn't let you enter [the refugee camp]?

Blanca: Those that were in charge up there, those that were in charge of getting the people out [of the war zones], because I was going to go with my mama and they sent me back to the border. From there they said, "This one is going to go with us," all of the people went up there, and all of the girls they sent back, they only let the old people and the little children stay.

Intrigued by the selection process, I had several informal conversations with my respondents about who granted refugee camp entrance, and what the entrance requirements were. I was told that the FMLN did indeed prevent young women from entering Honduran refugee camps, but only for the women's protection. Honduran soldiers reportedly accused all youthful women seeking refuge of being "guerillas" and denied their entrance into the camps, at times imprisoning, raping, or even killing them (I have since searched for confirmation that Honduran soldiers raped young females seeking refuge, and have not found any). I then questioned how the many women I had interviewed, who actually lived and worked in guerrilla camps, were able to leave the guerrilla camps for refugee camps when they became pregnant. These actual guerrillas apparently gained entrance without difficulty. "Of course," responded Gregoria, herself a guerrilla who gained entrance into a refugee camp while pregnant. "Young women were 'guerrillas,' but a pregnant woman, she had become a 'mother." These informal discussions provide further support for the idea that crisis, when combined with perceived biographical availability, made it very difficult for reluctant guerrillas to avoid mobilization despite their unwillingness to participate. Moreover, reluctant guerrillas who were mothers of young children were all eventually transferred to refugee camps, while reluctant guerrillas who were not mothers were expected to stay in the guerrillas unless, as in the case of Blanca, they, too, became pregnant. ${ }^{26}$

The case of reluctant guerrillas complicates the role of biography in the mobilization process. Young women, and women who were not mothers, had fewer options to escape activism than did older women who were mothers. Thus, biography not only influences an individual's internally held identity, it also influences the identity assigned to that individual by

\footnotetext{
${ }^{26}$ Many women who were childless when they joined the FMLN eventually left the guerrilla camps for the security of the refugee camps upon becoming pregnant. Several of my respondents even suggested that some women purposefully got pregnant when they tired of life in the guerrilla camp, as this guaranteed them safe escort to a refugee camp or repopulated community and a legitimate reason for exiting the fight for social justice.
} 


\section{American Journal of Sociology}

others. An external expectation of who "should" become a guerrilla limited the options available to young, childless women in wartime El Salvador.

The situational context of mobilization for reluctant guerrillas was characterized by extreme repression. Most went to guerrilla camps very early in the war when state violence was at its worst and knowledge of refugee camps was limited. Joining forces with one of the warring parties appeared to be the only means for survival. Most reluctant guerrillas did not appear to have other financial or network resources that might have allowed them to avoid guerrilla activism.

In sum, reluctant guerrillas were pushed into the guerrilla camps because they did not have the necessary networks or resources to escape a crisis by any other means. Network ties were not the impetus for mobilization, but they may have provided reluctant guerrillas an opportunity to escape massacres in their villages by fleeing to FMLN camps. Neither do biographical characteristics effectively distinguish reluctant guerrillas from others, although certain biographies did apparently limit some women's ability to not participate. Women who were young and childless were at times not allowed entrance into refugee camps because they fit an external role expectation of who "should" be a guerrilla. This concept of an external role expectation, unexplored in current mobilization literature, gains further relevance in the following section.

\section{Recruited Guerrillas}

[When I joined the guerrillas], I didn't have an objective, nothing more than seeing what it was like in the guerrillas, to have an adventure, nothing more.-Magaly

Recruited guerrillas lived in a refugee camp or a repopulated community, were specifically targeted by FMLN recruiters, and were persuaded to join the movement. They cite two common motivations. The first is the desire to have an adventure in the guerrillas. "I wanted to go," said Candelaria. "When you're young, you don't know why you go, you go because you see the rest in uniform, I guess." The second motivation is a desire for retribution. "I felt the desire," reported Elsy. "Like they say, I'm going to avenge myself, right, of all that they did to my family. . . . I wanted to fight like my father had fought. I wanted to defend, I wanted to release all of the bad that had happened to me." Lupe expressed a similar motivation. "We had always said that when we were big enough we were going to avenge the blood of my father and my sisters, and we did it." Recruited guerrillas' motivations differed from those of politicized guerrillas because they emphasized personal reasons (adventure and retribution) over more generalized political reasons (a sense of justice, seeking 


\section{Women's Mobilization}

political change). Recruited guerrillas' motivations differed from those of reluctant guerrillas because they chose to join the FMLN from the relative safety of a refugee camp and did not feel forced to join because of their situation.

With one exception, recruited guerrillas share a common network that facilitated their mobilization: they all lived in the confined community of a refugee camp or an FMLN-supported repopulation. ${ }^{27}$ This allencompassing network was strongly influenced by the FMLN; guerrillas or guerrilla supporters ran schools, organized protests, and even facilitated the transfer of supplies to FMLN combatants. Women living in refugee camps or repopulations were therefore frequently exposed to FMLN ideology and subjected to explicit invitations to join the guerrillas.

In the refugee camp, they would call together a big group of girls. They taught us politics, and said that we had to come and fight here with the Frente. There were political meetings, in school, that's where they prepared us [for the guerrillas].-Dolores

They arrived there and called together the people to talk about the motive of the war, what needed to be done. Of course they gave courses to motivate, to say that we had to fight, that we had to win this war. So you get animated-maybe with some little lies on their part, maybe-they would get you excited and you would come. Because of this a great number of adolescents left.-Marta

[The recruiters would come up to small groups of young women] and they would say to us: Bichas [young girls], don't you want to go and participate with us guerrillas? Yes!!! We're going to go!!! we said. We thought it was a real big thing, you know?-Candelaria

The effects of other network variables are not consistent (table 3). Only two of the seventeen had participated in prior organizational activities, and the respondents highlight networks of friends and schoolmates more often than familial networks in their mobilization narratives. These networks were easily and often targeted by FMLN recruiters within the confines of a refugee camp.

Biographically, recruited guerrillas were young, and all but one were

\footnotetext{
${ }^{27}$ Leonora did not live in a refugee camp or repopulation, but she did live in a community that was situated very near an FMLN base camp and subject to FMLN recruitment. She reports that "unos muchachos" from the FMLN camp would arrive often to talk with them about the war, and she remembers being especially motivated by the stories of the strong women living in the camps. She eventually decided to join the guerrillas.
} 


\section{American Journal of Sociology}

childless. ${ }^{28}$ Most had incomplete families. These biographies (no children to care for, fewer parents to prohibit guerrilla mobilization) certainly suggest few barriers to participation. Yet, as with reluctant guerrillas, biography also affected mobilization processes by determining whether women were perceived by the FMLN as potential participants and subsequently targeted for recruitment. To illustrate, refugee camp living technically freed mothers for guerrilla participation by providing food, education, health care, and day care services for young children, yet mothers were not generally invited to participate. Moreover, young refugee women who had lost a parent were significantly more likely to be targeted for recruitment than young refugee women with complete families. ${ }^{29} \mathrm{Re}-$ cruiters may have targeted women with incomplete families because they were perceived as having fewer barriers to participation, and also because they were perceived as most susceptible to recruitment messages framed around retribution (many parents were missing because they had been murdered by the Salvadoran Armed Forces). Biography therefore not only affects internally held identity, it also shapes the external role expectation of who "should" become a guerrilla.

Recruited guerrillas shared a highly homogenous situational context. All were mobilized in the latter part of the war and, for the most part, did not fear indiscriminate violence from the government armed forces. However, according to an FMLN commander, this time period also saw an expansion in the FMLN recruitment efforts:

When I arrived to El Tigre and was responsible for that zone, we had 114 combatants, including the personnel in supplies, medicine, explosives, propaganda, and the kitchen. When the war ended, we had nearly the same

\footnotetext{
${ }^{28}$ Although the ages of mobilization may seem extraordinarily young, interviews with commanders indicate that children as young as eight or nine were frequently active in the guerrilla camps. One female commander stated, "Nobody could live without their correitos" (little messengers). The one recruited guerrilla who had a child, Rosa, arrived at the refugee camp at age 18. Her compañero had stayed behind to fight with the guerrillas. When asked why she left the refugee camp to join the guerrillas, she said, "The commander practically obligated me to go," and then adds, "and I wanted to find out if my compañero was still alive." She left her child with her mother and returned to El Salvador to an FMLN camp. She is also the only recruited guerrilla who was mobilized early in the war, and the only mother recruited from a refugee camp.

${ }^{29}$ Each woman who joined the guerrillas from a refugee camp mentions being specifically recruited by a member of the FMLN. Of the 26 women living in refugee camps who decided not to join the guerrillas, only 3 of the 12 women with complete families $(25 \%)$ were invited to join the guerrillas, whereas 7 of the 14 with incomplete families (50\%) received an invitation. The variables "complete family" and "invitation to join guerrillas" were significantly and negatively correlated at the .05 level among all refugee camp residents (Spearman's $\rho=-.306$ ), indicating that FMLN recruiters were specifically targeting young women with limited parental control.
} 


\section{Women's Mobilization}

number of people, but from the initial group to the final group, only 17 of us survived. One by one, our compas fell and were substituted by others, and then they fell as well. What we had in the end was like a third generation. Such human waste forced certain levels of flexibility [in recruitment practices].

He went on to say that, given the very basic need for bodies, it became common late in the war to give entrance to "people motivated purely by the desire for adventure."

In sum, recruited guerillas were persuaded to leave the refugee camps for the guerrilla camps by a member of the FMLN. They were not invited to participate because they shared common ideologies with the guerrillas, but rather were identified by their perceived biographical availability. Recruitment messages were unavoidable and appealed to women's emotions; all recruited guerrillas frame their mobilization as an effort to avenge the death of loved ones or to seek adventure outside refugee camp walls.

In the preceding section, I analyzed the interaction of women's networks, biographies, and situational context in relation to their stated motivations for guerrilla participation, and I concluded that women followed three distinct paths to the guerrilla camps. Next, I test these three mobilization paths against my control group of nonguerrillas: collaborators and nonparticipants.

\section{Comparing Guerrillas and Collaborators}

Twelve women in this study collaborated extensively with the FMLN guerrilla army while maintaining a permanent residence at home. Collaborating did not involve all the sacrifices of guerrilla participation, but it was high risk nonetheless. If government soldiers identified a woman as a collaborator, she would likely be killed or imprisoned. Most collaborators hiked to a nearby guerrilla camp several days per week to cook for the combatants. Others made food in their homes and then carried the food to a nearby camp. At times, these women traveled to nearby communities to buy supplies and leave them at predesignated drop-off locations. Only two of the 12 collaborators in this study did not provide direct support to FMLN camps. These two collaborators worked in neighboring countries garnering political support and promises of aid for the guerrilla movement.

Women cited two reasons for participating as FMLN collaborators. Most (75\%) collaborated because they believed the cause was just. Magdalena, for example, said, "I became aware of the social inequality that existed," and Susana stated that "I recognized that it was right, you know, to do something, even just a little something . . . because I felt it was 


\section{American Journal of Sociology}

necessary, you know . . . and it's a sin not to do what you can do, to make things better for yourself and for others."

However, a minority (25\%) reports collaborating as a means of survival. When asked why she and her family collaborated with the FMLN, Marina responded:

Marina: Because at that time you couldn't get anything to eat in town. We only ate bananas, that was the food we had. There was no corn, no beans, no rice, not even soap. Nothing.

Interviewer: So how did you cook for the guerrillas?

Marina: They brought us the food, because they could get it. They brought everything: corn, rice, beans. Who knows how they did it, but they could get things.

Interviewer: So you ate better?

Marina: Once we started to support them, yes, they gave us our food.

The objective conditions of collaborators are listed in table 4. Fifty percent were members of political organizations prior to their guerrilla collaboration. Few ever lived in refugee camps, and most had family members active in the guerrillas.

Biographically, collaborators are best divided into two groups: single mothers and young women with complete families. The first group comprises seven mothers, four of whom were active in political organizations before the war. Three were single mothers when the war began, and four became single mothers when their compañeros joined the guerrillas. Several suggested they would have joined the guerrillas were it not for their children. Susana, for example, said she chose not to live in an FMLN camp "because I had many little children, I had five young children, and so I said 'No, no I can't.' This, yes, makes me feel weak. I didn't have the courage to leave the kids somewhere else."

The second group, young women with complete families, apparently did not flee to refugee camps because their parents wanted to maintain their homes and their freedom during the war. They often collaborated with the guerrillas as a way to survive, but also as a bargaining tool to keep their daughters out of the guerrilla camps. Several of these young women stated that they wished to join the FMLN, and in fact were often recruited by the guerrillas with whom they collaborated. Guerrilla life seemed more secure than living in war-torn El Salvador. However, the women's parents actively and forcefully prevented their mobilization. For example, Marina's mother told her that if she were to join the guerrillas, her family would disown her. Marina joined anyway at age 13, but her mother used her guerrilla contacts and her pull as a collaborator to find her daughter and have her brought home a mere three months later. Celestina recalls wanting to join the guerrillas after several frightening 
TABLE 4

Objective Conditions of Collaborators and Nonparticipants

\begin{tabular}{|c|c|c|c|c|c|}
\hline Respondent & Motherhood $^{a}$ & $\begin{array}{l}\text { Complete } \\
\text { Family }\end{array}$ & $\begin{array}{l}\text { Refugee } \\
\text { Camp }^{\text {b }}\end{array}$ & $\begin{array}{c}\text { Previous } \\
\text { Organizational } \\
\text { Involvement }\end{array}$ & $\begin{array}{l}\text { Family } \\
\text { Members } \\
\text { Active }\end{array}$ \\
\hline \multicolumn{6}{|l|}{ Collaborators: } \\
\hline Francesca ..... & $\mathrm{X}$ & & $\mathrm{X}$ & & $\mathrm{X}$ \\
\hline Eva ........... & $\mathrm{X}$ & & $\mathrm{X}$ & $\mathrm{X}$ & $\mathrm{X}$ \\
\hline Susana ........ & $\mathrm{X}$ & & & $\mathrm{X}$ & $\mathrm{X}$ \\
\hline Tina ............ & $\mathrm{X}$ & & & & $\mathrm{X}$ \\
\hline Griselda ........ & $\mathrm{X}$ & & & & $\mathrm{X}$ \\
\hline Lisa $\ldots \ldots \ldots \ldots$ & 1984 & $\mathrm{X}$ & $\mathrm{X}$ & $\mathrm{X}$ & $\mathrm{X}$ \\
\hline Nina $\ldots . . . . .$. & 1984 & $\mathrm{X}$ & & $\mathrm{X}$ & $\mathrm{X}$ \\
\hline Nela ........... & & $\mathrm{X}$ & $\mathrm{X}$ & $\mathrm{X}$ & $\mathrm{X}$ \\
\hline Celestina ...... & & $\mathrm{X}$ & & & $\mathrm{X}$ \\
\hline Marina ......... & & $\mathrm{X}$ & & & $\mathrm{X}$ \\
\hline Magdalena ... & & $\mathrm{X}$ & & $\mathrm{X}$ & $\mathrm{X}$ \\
\hline Deisy .......... & & & & & \\
\hline \multicolumn{6}{|l|}{ Nonparticipants: } \\
\hline Perona ......... & $\mathrm{X}$ & $\mathrm{X}$ & $\mathrm{X}$ & & $\mathrm{X}$ \\
\hline Prudencia ..... & $\mathrm{X}$ & $\mathrm{X}$ & $\mathrm{X}$ & & $\mathrm{X}$ \\
\hline Teresa .......... & $\mathrm{x}$ & $\mathrm{X}$ & $\mathrm{X}$ & & \\
\hline Clara .......... & $\mathrm{X}$ & & $\mathrm{X}$ & & $\mathrm{X}$ \\
\hline Virginia $\ldots \ldots \ldots$ & $\mathrm{X}$ & & $\mathrm{X}$ & & $\mathrm{X}$ \\
\hline Elena $\ldots \ldots \ldots$ & $\mathrm{X}$ & & $\mathrm{X}$ & & $\mathrm{X}$ \\
\hline Ines $\ldots \ldots \ldots$ & $\mathrm{X}$ & & $\mathrm{X}$ & & $\mathrm{X}$ \\
\hline Norma ......... & $\mathrm{X}$ & & & & $\mathrm{X}$ \\
\hline Nidia ........... & $\mathrm{X}$ & $\mathrm{X}$ & & & $\mathrm{X}$ \\
\hline Flor $\ldots \ldots \ldots$ & $\mathrm{X}$ & $\mathrm{X}$ & & $\mathrm{X}$ & \\
\hline Erlinda $\ldots . . .$. & $\mathrm{x}$ & & & & $\mathrm{X}$ \\
\hline Morena ....... & 1986 & $\mathrm{X}$ & $\mathrm{X}$ & & $\mathrm{X}$ \\
\hline Olga $\ldots \ldots \ldots \ldots$ & 1990 & $\mathrm{X}$ & $\mathrm{X}$ & & $\mathrm{X}$ \\
\hline Daniela ....... & 1987 & $\mathrm{X}$ & $\mathrm{X}$ & & $\mathrm{X}$ \\
\hline Cornelia ...... & 1986 & $\mathrm{X}$ & $\mathrm{X}$ & & $\mathrm{X}$ \\
\hline Gilda .......... & 1989 & & $\mathrm{X}(\mathrm{SS})$ & & $\mathrm{X}$ \\
\hline Isabela ......... & 1985 & & X (SS) & & $\mathrm{X}$ \\
\hline Dorotea ....... & 1988 & $\mathrm{X}$ & & & \\
\hline Doti $\ldots \ldots \ldots \ldots$ & 1986 & & & & \\
\hline Lola ............ & 1990 & & & & \\
\hline Monica ......... & & $\mathrm{X}$ & $\mathrm{X}$ & & $\mathrm{X}$ \\
\hline Feliciana ...... & & $\mathrm{X}$ & $\mathrm{X}$ & & $\mathrm{X}$ \\
\hline Adela .......... & & & $\mathrm{X}$ & & $\mathrm{X}$ \\
\hline Concepcion ... & & & $\mathrm{X}$ & & $\mathrm{X}$ \\
\hline Vicenta ........ & & & $\mathrm{X}$ & & $\mathrm{X}$ \\
\hline Orbelina ...... & & & $\mathrm{X}$ & & $\mathrm{X}$ \\
\hline Ancelma ...... & & & $\mathrm{X}$ & & $\mathrm{X}$ \\
\hline Alejandra ..... & & & $\mathrm{X}(\mathrm{SS})$ & & $\mathrm{X}$ \\
\hline
\end{tabular}


American Journal of Sociology

TABLE 4 (Continued)

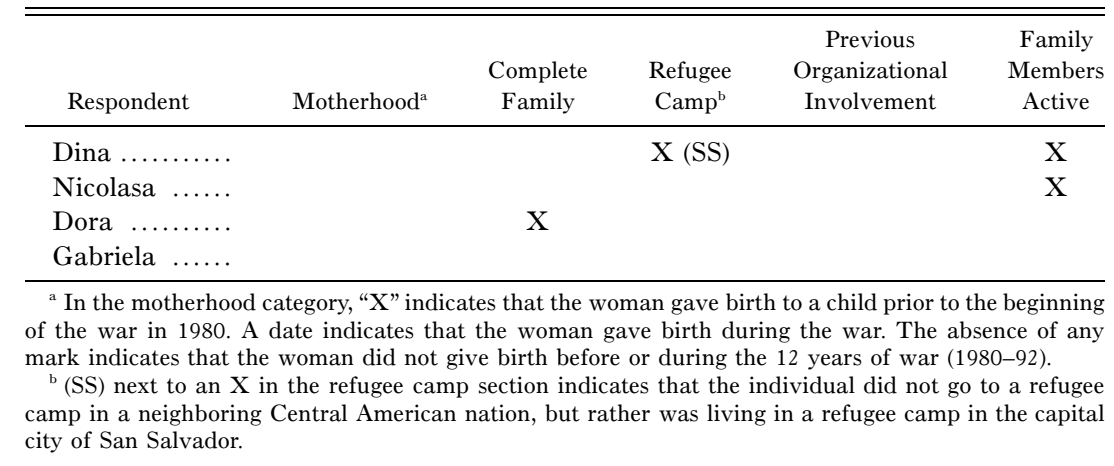

encounters with the Salvadoran Armed Forces, but her parents intervened. They invoked their own participation to gain power, telling recruiters that they would continue their collaboration as long as their daughters were left at home. They reminded recruiters that their two older sons were guerrillas and claimed, "Two is enough." Moreover, when they heard that recruiters were coming to the village, they sent their daughters to run errands or visit family in other towns.

In sum, collaborators, and especially collaborators who are mothers, share some mobilization characteristics with politicized guerrillas. A relatively large proportion was involved in previous organizational activities, and most cited political reasons for their involvement. However, collaborating mothers did not take the next step to guerrilla participation because they had young children at home. Collaborating nonmothers did not join because they were not living in high recruitment areas like refugee camps or repopulations, and because they had complete families that actively prevented their guerrilla mobilization. I also speculate that reluctant guerrillas who were mothers and had previous organizational involvement may have been collaborators had they not been forced into guerrilla camps by crisis.

Data on collaborators, although not as clearly patterned as data on guerrillas, highlight how the same mobilization factors (networks, biographies, and situational context) can have different results in different combinations. For example, having parents who support the FMLN does not guarantee that they will also support their child's participation in the guerrilla army. The child's own organizational membership, the parents' history of organizational membership, and the situational context (here, absence of crisis, the latter period of the war), are intervening factors.

These data also clarify contradictory viewpoints on the relationship between motherhood and mobilization. Women who were household 


\section{Women's Mobilization}

heads, activists, and mothers did support the revolutionary cause, but typically as collaborators, not as guerrillas. This counters Reif-Lobao's (1986, 1998) and Mason's (1992) claims that these roles, when met with repression, inspired guerrilla mobilization. Motherhood, and in particular the presence of young children, was a barrier to guerrilla activism, but not to guerrilla collaboration.

\section{Comparing Guerrillas and Nonparticipants}

The last test of my typology is whether nonguerrillas also share the combinations of factors that I argue lead to guerrilla mobilization (table 4). Unlike politicized guerrillas, few nonparticipants took part in previous political organizations. Unlike reluctant guerrillas, most nonparticipants with crises had the necessary resources to reach a refugee camp. At least five of the nonparticipants (Nicolasa, Lola, Dorotea, Doti, and Gabriela) never had to flee a crisis at all and lived in areas less touched by conflict. Unlike recruited guerrillas, most nonparticipants living in refugee camps had a complete family and did not have a history of political involvement. The few women in refugee camps who did report incomplete families and previous organizational involvement did not go to a refugee camp in Honduras. Rather, they went to refugee camps near the capital city of San Salvador, where guerrilla recruitment efforts seldom reached. In all, only five of the 32 nonparticipants shared similar characteristics with the recruited guerrillas in that they were young, childless, had incomplete families, and lived in refugee camps or repopulations. Of these five, two were very young at the time of the interview (23 and 24 years old), which would have lowered their possibilities of recruitment in the late 1980s when they would have been just 8 or 9 years old. The remaining three women, Vicenta, Orbelina, and Ancelma, explained their lack of willingness to join the guerrillas as simple fear. They preferred the security of the refugee camps to the dangers of guerrilla warfare.

\section{Summarizing the Results}

In table 5, I list the correlations of each mobilization variable (networks, biographies, situational context) with each of the three paths to mobilization. The results are consistent with the qualitative analysis. Politicized guerrillas are significantly more likely to have previous organizational involvement, no refugee camp experience, a complete family, and to mobilize early in the war. Reluctant guerrillas are more likely to be older, to be mothers, to mobilize early in the war, and, although suffering displacement, are not initially able to enter refugee camps. Recruited guerrillas are distinguished by their location in a refugee camp or repopulation, 
TABLE 5

Bivariate Correlations (Spearman's $\rho$ ) Between Selected Mobilization Characteristics and Women's Wartime Participation Category

\begin{tabular}{|c|c|c|c|c|c|}
\hline Variable & $\begin{array}{c}\text { Politicized } \\
\text { Guerrillas }\end{array}$ & $\begin{array}{l}\text { Reluctant } \\
\text { Guerrillas }\end{array}$ & $\begin{array}{l}\text { Recruited } \\
\text { Guerrillas }\end{array}$ & Collaborators & Nonparticipants \\
\hline \multicolumn{6}{|l|}{ Networks: } \\
\hline Previous organizational involvement $\ldots \ldots$ & $.505^{* *}$ & .164 & -.174 & $.217 *$ & $-.428 * *$ \\
\hline Family ties $\ldots \ldots \ldots \ldots \ldots \ldots \ldots \ldots \ldots$ & -.081 & .047 & .009 & .107 & -.074 \\
\hline Refugee/repopulated community & $-.319 * *$ & $-.474 * *$ & $.436 * *$ & -.123 & $.273 * *$ \\
\hline \multicolumn{6}{|l|}{ Biographical availability: } \\
\hline Motherhood & -.074 & $.252 *$ & $-.385 * *$ & .088 & .119 \\
\hline Complete family $\ldots \ldots \ldots \ldots \ldots \ldots \ldots \ldots \ldots$ & $.300 * *$ & -.158 & $-.219 *$ & 133 & .039 \\
\hline Age of entry $\ldots \ldots \ldots \ldots$. & 199 & $.417 * *$ & $-.560 * *$ & & \\
\hline \multicolumn{6}{|l|}{ Situational context: } \\
\hline Mobilization period & $-.315^{*}$ & $-.615 * *$ & $.842 * *$ & & \\
\hline$N$ & 7 & 14 & 17 & 12 & 32 \\
\hline
\end{tabular}

${ }_{* *}^{*} P<.05$, one-tailed tests.

$P<.0$ 


\section{Women's Mobilization}

their biographical availability in terms of age and motherhood, their loss of a parent, and their late-war mobilization. Neither reluctant nor recruited guerrillas necessitate prior organizational experience for mobilization, and none of the three groups were dependent on family ties for mobilization. Unlike the initial comparison of guerrillas and nonguerrillas (table 2), the use of these multiple paths successfully distinguishes guerrillas from nonguerrillas, and provides a better understanding of the diversity of mobilization experiences among women guerrillas in El Salvador.

\section{CONCLUSIONS}

Using a rare representative sample of activists and nonactivists, I identify three distinct mobilization patterns that consistently led rural Salvadoran women to involvement in the FMLN guerrilla army: politicized, reluctant, and recruited guerrillas. I conclude by discussing the implications of these findings for studies of women guerrillas and revolutionary movements specifically, as well as for studies of microlevel mobilization processes in general.

Implications for Research on Women Guerrillas and Revolutionary Movements

This study improves our understanding of the mobilization processes that led impoverished women in patriarchal societies to participate in guerrilla armies. Previous research highlights the importance of networks (prior organizational involvement and family ties to activists), the absence of biographical barriers, and a situation of repression. My research confirms the importance of these factors but enhances our understanding of how each works individually and in combination with one another.

First, with regard to networks, I find that the organizational involvement cited as critical in all previous studies is central to some women's mobilization, but not to most. The importance of family ties to activists is also questioned; nearly all women in war zones, both guerrillas and nonguerrillas, had close family members serving the FMLN. I add to existing explanations the critical role of refugee camps as organizational sites of mobilization for many women guerrillas. The all-encompassing, totalizing nature of membership in a refugee camp may account for its particular effectiveness in propelling young, childless women into guerrilla armies.

Second, this study reiterates the importance of biography for explaining women's guerrilla mobilization. However, the ways in which biography 


\section{American Journal of Sociology}

matter are much more complex than the literature suggests. Biography not only influences a woman's internal participation decision, it also shapes the external role expectation held by powerful others who may have the ability to influence, or at times even require, her guerrilla participation. In the case of guerrilla activism, young, childless women were particularly vulnerable to recruitment, while women who were mothers or who had complete families were often protected from pressures to participate.

Third, previous conceptualizations of the effects of repression are too static. Levels and types of repression changed greatly over the course of the war, and this variation had a direct impact on how, when, and why women mobilized. Early in the war, repression directly mobilized even unlikely participants (women, young and old, with and without children, in patriarchal societies, and with no past political involvement) through mass dislocation and chaos. Later in the war, repression indirectly mobilized a more select group of women because earlier repressive periods forcefully forged new networks (within refugee camps and repopulations) and gave new meaning to existing biographies (young and childless), and these changes then continued to powerfully shape mobilization processes long after the repression itself subsided. Yet in contrast with previous studies, I do not find that repression was a catalyst pushing already active women into the guerrillas. Rather, politically active women appear to have been pulled into clandestine activism by their already strong participation identities.

Finally, whereas previous studies propose one "typical" route to activism, I find that the variable interaction of networks, biographies, and situational contexts created three distinct paths to guerrilla participation for rural Salvadoran women. Moreover, the proposed "typical" path, most closely exemplified by politicized guerrillas, accounted for only a small portion of the guerrillas I interviewed. ${ }^{30}$ By contrast, I find that most

${ }^{30}$ As noted in the data section, the only significant correlation that I found between present-day attitudes/actions and past mobilization categories was that between the present-day action of holding a leadership position in the community and the past category of politicized guerrilla. But establishing the existence of a relationship does not distinguish causality. Does mobilizing for political reasons in the past make one more likely to become a community leader in the present? Or does being a presentday leader make one more likely to remember one's past mobilization as arising from political consciousness? If the first explanation were true, it would do little to undermine the politicized guerrilla configuration as a likely causal path to guerrilla participation and would indicate that at least some women were mobilized by what existing literature suggests is the typical path. If the second explanation were true, and present-day community leaders impose more political consciousness on their past actions than what was initially there, it would cast further doubt on existing arguments that women's guerrilla activism arose out of women's earlier political activism in other, peaceful 


\section{Women's Mobilization}

women's mobilization was either directly (reluctant guerrillas) or indirectly (recruited guerrillas) motivated by state-sponsored repression, and not by previous political participation.

This microlevel finding has important implications for macrolevel explanations of popular mobilizations. Specifically, my analysis of women's guerrilla mobilization in El Salvador supports and extends Goodwin's (2001) model of popular revolutionary activism. In his cross-national comparison, Goodwin finds that repressive state structures mobilize antistate dissent through their use of indiscriminate violence, and in effect leave citizens with "no other way out" than revolution (Goodwin 2001). The experiences of my respondents verify the central role of state-sponsored repression for generating grassroots mobilization when individuals have no other way out. But my data further suggest that the more central role of repression in generating popular mobilization is in creating effective recruitment environments, and resounding recruitment frames, that movement leaders can then use to grow their movement. This recruitment may actually become most effective after state-sponsored repression subsides and movement leaders have more and better opportunities to pursue recruitment activities. Future studies of revolution should take into account how the changing intensity and motives of state-level repression may in turn generate new openings for movements' recruitment efforts.

The macrolevel implications of this study also extend to the maintenance and consequences of revolutionary mobilizations. For example, the different paths that individuals take to revolutionary mobilizations may in turn influence their long-term commitment to the movement. Can unwilling participants be converted into ideological supporters of the cause and be encouraged to stay involved, or will they leave their activist role behind at the first opportune moment? Likewise, the current literature on women revolutionaries continues to debate the consequences of women's revolutionary participation for whether women win new rights under new democracies. This study suggests that whether and how women continue their activism after the war may depend in part on their varied paths to participation. Will women guerrillas, who mobilized around identities and frames that were not connected to the traditional gender role of motherhood, carry their activism forward to new forms of postwar participation? Or will women who were "pushed" and "persuaded" into guerrilla participation return to more traditional gender roles once the war has ended?

organizations. If there is error in my data, that error would likely overestimate the already small size of the category politicized guerrilla. 
American Journal of Sociology

Broader Implications for Studies of Mobilization

The implications of this study extend far beyond women's guerrilla activism and theories of revolutionary change. This study clearly demonstrates that identifying multiple paths to the same mobilization outcome is both possible and desirable for many microlevel analyses of mobilization.

Identifying multiple, conjunctural paths to the same mobilization outcome is possible. Mobilization is the result of the patterned interaction of individual-level biography, networks, and situational context. Because these processes are patterned, scholars can identify the different paths that individuals follow to participation while still prioritizing parsimonious explanations.

Identifying multiple, conjunctural paths to participation is also desirable. I highlight three reasons. First, it rests on solid theoretical foundations. Activists are heterogenous; networks compete for identity salience within individuals; the same situational context affects different individuals differently given their unique biographies and network resources; networks, biographies, and contexts all shift over the course of a movement. Studies seeking one, generalized path to mobilization cannot capture these processes.

Second, this method is desirable because it is empirically more effective at distinguishing activists from nonactivists, and therefore it is better at capturing real-world mobilization processes than studies seeking one generalized mobilization path. Forcing uniformity on what in reality are distinct processes can generate inaccurate conclusions about which factors matter for mobilization, and even whether certain factors promote or inhibit activism. In the case of women guerrillas, several critical mobilization factors did not appear to distinguish activists from nonactivists, when in reality these factors had contradictory effects on mobilization that could not be ascertained without analyzing that variable in conjunction with others. For example, living in a refugee camp inhibited guerrilla mobilization for mothers and for young women with complete families by isolating them from crises, but it promoted mobilization for young, childless women who were missing a parent by making them vulnerable to recruitment. Likewise, complete families significantly contributed to the mobilization of politicized guerrillas, because this family structure was embedded in other networks that prioritized political involvement during a climate of political agitation early in the war. By contrast, having a complete family later in the war, and especially while living in a refugee camp or a repopulated area, inhibited mobilization. Even the role of biographical availability is variable: early in the war, biography was not as important for mobilization as membership in po- 


\section{Women's Mobilization}

litical organizations or being victimized by repression, but later in the war, biography intersects with new networks and the changing context to become the critical determinant of recruitment patterns, even among individuals without prior political experience.

Finally, examining mobilization in a conjunctural manner is desirable because it extends our knowledge of how each component causal factor operates within the broader mobilization process. As demonstrated above, scholars interested in the effects of repression on mobilization can identify when, how, and under what circumstances repression matters if they study repression in conjunction with individual biographies, networks, and changing structural contexts. Likewise, analyses of gender often highlight the role of motherhood in promoting women's revolutionary activism, yet looking at motherhood in conjunction with other mobilization factors makes clear that the meaning of motherhood varies according to individuals' networks, situational contexts, and the changing expectations placed on the motherhood role by powerful others. Identifying conjunctural paths to mobilization has the potential to deepen our sociological knowledge of whether and how specific biographical characteristics (e.g., gender, race, class, age, sexuality, etc.), network memberships (e.g., political organizations, religious organizations, unions, family ties, neighborhoods, etc.), or changing situational contexts (e.g., democratic transitions, state repression, increasing globalization, etc.) contribute to popular mobilization.

\section{REFERENCES}

Auyero, Javier. 1999. "Remembering Peronism: An Ethnographic Account of the Relational Character of Political Memory." Qualitative Sociology 22 (4): 331-51.

Bayard de Volo, Lorraine. 2001. Mothers of Heroes and Martyrs: Gender Identity Politics in Nicaragua, 1979-1999. Baltimore: Johns Hopkins University Press.

Bearman, Peter. 1993. Relations into Rhetorics: Local Elite Social Structure in Norfolk, England, 1540-1640. New Brunswick, N.J.: Rutgers University Press

Beckett, Megan, Maxine Weinstein, Noreen Goldman, and Lin Yu-Husan. 2000. "Do Health Interview Surveys Yield Reliable Data on Chronic Illness among Older Respondents?" American Journal of Epidemiology 151:315-23.

Belli, Robert F., William L. Shay, and Frank P. Stafford. 2001. "Event History Calendars and Question List Surveys: A Direct Comparison of Interviewing Methods." Public Opinion Quarterly 65:45-74.

Blau, Peter M., and Otis Dudley Duncan. 1967. The American Occupational Structure. New York: John Wiley.

Bouvard, Marguerite Guzman. 2002. Revolutionizing Motherhood: The Mothers of the Plaza de Mayo. Lanham, Md.: SR Books.

Bradley, Margaret M. 1994. "Emotional Memory: A Dimensional Analysis." Pp. 97-134 in Emotions: Essays on Emotion Theory, edited by Stephanie H. M. van Goozen, Nanne E. Van Poll, and Joseph A. Sergeant. Hillsdale, N.J.: Lawrence Erlbaum Associates.

Briet, Martien, Bert Klandermans, and Frederike Kroon. 1987. "How Women Become 


\section{American Journal of Sociology}

Involved in the Women's Movement." Pp. 44-64 in The Women's Movements in the U.S. and Western Europe: Consciousness, Political Opportunity and Public Policy, edited by M. Katzenstein and C. Mueller. Philadelphia: Temple University Press.

Brown, Norman R., and Donald Schopflocher. 1998. "Event Clusters: An Organization of Personal Events in Autobiographical Memory." Psychological Science 9:470-75.

Byrne, Hugh. 1996. El Salvador's Civil War: A Study of Revolution. Boulder, Colo.: Lynne Rienner.

Cagan, Beth, and Steve Cagan. 1991. This Promised Land, El Salvador. New Brunswick, N.J.: Rutgers University Press.

Calhoun, Craig. 1991. "The Problem of Identity in Collective Action." Pp. 51-75 in Macro-Micro Linkages in Sociology, edited by J. Huber. Newbury Park, Calif.: Sage.

- ed. 1994. Social Theory and the Politics of Identity. Cambridge, Mass.: Blackwell.

Chinchilla, Norma Stoltz. 1983. "Women in Revolutionary Movements: The Case of Nicaragua." Pp. 422-35 in Revolution in Central America, edited by the Stanford Central America Action Network. Boulder, Colo.: Westview.

Commission on the Truth. 1993. "From Madness to Hope: The 12-Year War in El Salvador." U.S. Institute of Peace. http:// www.usip.org/library/tc/doc/reports/ el_salvador/tc_es_03151993_toc.html.

della Porta, Donatella. 1988. "Recruitment Processes in Clandestine Political Organizations: Italian Left-Wing Terrorism.” Pp. 155-69 in International Social Movement Research, vol. 1, edited by S. Tarrow, B. Klandermans, and H. Kriesi. Greenwich, Conn.: JAI Press.

Dodson, Michael, and Laura Nuzzi O'Shaugnessy. 1985. "Religion and Politics." Pp. 119-44 in Nicaragua: The First Five Years, edited by T. Walker. New York: Praeger.

El-Bushra, Judy, and E. Piza Lopez. 1994. Development in Conflict: The Gender Dimension. Oxford: Oxfam.

El-Bushra, Judy, and Cécile Mukarubuga. 1995. "Women, War and Transition.” Gender and Development 3:16-21.

Emirbayer, Mustafa, and Jeff Goodwin. 1994. "Network Analysis, Culture, and the Problem of Agency." American Journal of Sociology 99:1411-54.

Enloe, Cynthia. 1990. "Bananas, Bases and Patriarchy." Pp. 189-205 in Women, Militarism and War: Essays in History, Politics, and Social Theory, edited by J. Bethke Elshtain and S. Tobias. Savage, Md.: Rowman and Littlefield.

Fernandez, Roberto M., and Doug McAdam. 1988. "Social Networks and Social Movements: Multiorganizational Fields and Recruitment to Mississippi Freedom Summer." Sociological Forum 3:357-82.

Ferree, Myra Marx, and Carol McClurg Mueller. 2004. "Feminism and the Women's Movement: A Global Perspective." Pp. 576-607 in The Blackwell Companion to Social Movements, edited by David A. Snow, Sarah A. Soule, and Hanspeter Kriesi. Malden, Mass.: Blackwell.

Goldstone, Jack A. 1991. Revolution and Rebellion in the Early Modern World. Berkeley and Los Angeles: University of California Press.

Goodwin, Jeff. 2001. No Other Way Out: States and Revolutionary Movements, 1945-1991. Cambridge: Cambridge University Press.

Gould, Roger V. 1995. Insurgent Identities: Class, Community, and Protest in Paris from 1848 to the Commune. Chicago: University of Chicago Press.

Henig, Jeffrey. 1982. Neighborhood Mobilization, Redevelopment and Response. New Brunswick, N.J.: Rutgers University Press.

Irons, Jenny. 1998. "The Shaping of Activist Recruitment and Participation: A Study of Women in the Mississippi Civil Rights Movement." Gender and Society 12 (6): 692-709.

Kampwirth, Karen. 2002. Women and Guerrilla Movements: Nicaragua, El Salvador, Chiapas, Cuba. University Park: Pennsylvania State University Press. 


\section{Women's Mobilization}

Kim, Hyojoung, and Peter S. Bearman. 1997. "The Structure and Dynamics of Movement Participation." American Sociological Review 49:583-600.

Klandermans, Bert. 1984. "Mobilization and Participation: Social Psychological Expansions of Resource Mobilization Theory." American Sociological Review 49: 583-600.

Klandermans, Bert, and Dirk Oegema. 1987. "Potentials, Networks, Motivations, and Barriers: Steps towards Participation in Social Movements." American Sociological Review 52:519-31.

Kriger, Norma. 1992. Zimbabwe's Guerrilla War: Peasant Voices. Cambridge: Cambridge University Press.

Larana, Enrique, Hank Johnston, and Joseph R. Gusfield, eds. 1994. New Social Movements: From Ideology to Identity. Philadelphia: Temple University Press

Loveman, Mara. 1998. "High-Risk Collective Action: Defending Human Rights in Chile, Uruguay, and Argentina." American Journal of Sociology 104:477-525.

Luciak, Ilja A. 2001. After the Revolution: Gender and Democracy in El Salvador, Nicaragua, and Guatemala. Baltimore: Johns Hopkins University Press.

Markus, Gregory B. 1986. "Stability and Change in Political Attitudes: Observed, Recalled, and 'Explained." Political Behavior 8 (1): 21-44.

Mason, David T. 1992. "Women's Participation in Central American Revolutions: A Theoretical Perspective." Comparative Feminist Studies 25 (1): 63-89.

Massey, Douglas S. and Rene Zenteno. 2000. "A Validation of the Ethnosurvey: The Case of Mexico-US Migration.” International Migration Review 34:765-92.

McAdam, Doug. 1986. "Recruitment to High-Risk Activism: The Case of Freedom Summer." American Journal of Sociology 92:64-90.

- 1992. "Gender as the Mediator of the Activist Experience: The Case of Freedom Summer." American Journal of Sociology 97:1211-40.

- 2000. Introd. to Political Process and the Development of Black Insurgency, 1930-1970, 2d ed. Chicago: University of Chicago Press.

McAdam, Doug, and Ronnelle Paulsen. 1993. "Specifying the Relationship between Social Ties and Activism." American Journal of Sociology 99 (3): 640-67.

McClintock, Cynthia. 1998. Revolutionary Movements in Latin America: El Salvador's FMLN and Peru's Shining Path. Washington, D.C.: United States Institute of Peace Press.

Migdal, Joel S. 1974. Peasants, Politics, and Revolution: Pressures toward Political and Social Change in the Third World. Princeton, N.J.: Princeton University Press.

Miller, Chet C., Laura B. Cardinal, and William H. Glick. 1997. "Retrospective Reports in Organizational Research: A Reexamination of Recent Evidence." Academy of Management Journal 40 (1): 189-204.

Molyneux, Maxine. 1985. "Mobilization without Emancipation? Women's Interests, State and Revolution in Nicaragua." Feminist Studies 11 (2): 227-53.

Morris, Aldon. 1984. The Origins of the Civil Rights Movement: Black Communities Organizing for Change. New York: Free Press.

Murguialday, Clara, ed. 1996. Montañas con Recuerdos de Mujer: Una mirada feminista a la participación de las mujeres en los conflictos armadas en Centroamérica y Chiapas. San Salvador: Mujeres por la Dignidad y la Vida (Las Dignas).

Murguialday, Clara, Mercedes Olivera, and Norma Vásquez, eds. 1997. Y La Montaña Habló: Testimonios de guerrilleras y collaboradoras del FMLN. San Salvador: Mujeres por la Dignidad y la Vida (Las Dignas).

Naples, Nancy A. 1998. Grassroots Warriors: Activist Mothering, Community Work, and the War on Poverty. New York: Routledge.

Nepstad, Sharon Erickson, and Christian Smith. 1999. "Rethinking Recruitment to High-Risk/Cost Activism: The Case of Nicaragua Exchange." Mobilization 4 (1): 25-40. 


\section{American Journal of Sociology}

Neuhouser, Kevin. 1995. "Worse than Men: Gendered Mobilization in an Urban Brazilian Squatter Settlement, 1971-91." Gender and Society 9:38-59.

New Americas Press, ed. 1989. A Dream Compels Us: Voices of Salvadoran Women. Boston: South End Press.

Noonan, Rita K. 1995. "Women against the State: Political Opportunities and Collective Action Frames in Chile's Transition to Democracy." Sociological Forum 10 (1): $81-111$.

Olson, Mancur. 1965. The Logic of Collective Action. Cambridge, Mass.: Harvard University Press.

Paige, Jeffery M. 1975. Agrarian Revolution: Social Movements and Export Agriculture in the Underdeveloped World. New York: Free Press.

- 1997. Coffee and Power: Revolution and the Rise of Democracy in Central America. Cambridge, Mass.: Harvard University Press.

Pfaff, Steven. 1996. "Collective Identity and Informal Groups in Revolutionary Mobilization” Social Forces 75 (1): 91-118.

Popkin, Samuel L. 1979. The Rational Peasant: The Political Economy of Rural Society in Vietnam. Berkeley and Los Angeles: University of California Press.

Reif-Lobao, Linda L. 1986. "Women in Latin American Guerrilla Movements: A Comparative Perspective." Comparative Politics 18 (2): 147-69.

- 1998. "Women in Revolutionary Movements: Changing Patterns of Latin American Guerrilla Struggle." Pp. 255-90 in Women and Revolution: Global Expressions, edited by M. J. Diamond. AA Dordrecht: Kluwer Academic Publishers. Saywell, Shelley. 1985. Women in War. New York: Viking.

Schacter, Daniel L. 1996. Searching for Memory: The Brain, the Mind, and the Past. New York: Basic.

Schwartz, Barry. 1997. "Collective Memory and History: How Abraham Lincoln Became a Symbol of Racial Equality.” Sociological Quarterly 38 (3): 469-96.

Scott, Jacqueline, and Duane Alwin. 1998. "Retrospective versus Prospective Measurement of Life Histories in Longitudinal Research.” Pp. 98-127 in Methods of Life Course Research: Qualitative and Quantitative Approaches, edited by Glen Elder, Jr., and Janet Ziele. Thousand Oaks, Calif.: Sage.

Scott, James C. 1976. The Moral Economy of the Peasant: Rebellion and Subsistence in Southeast Asia. New Haven, Conn.: Yale University Press.

Skaine, Rosemarie. 1999. Women at War: Gender Issues of Americans in Combat. Jefferson, N.C.: McFarland.

Skocpol, Theda. 1979. States and Social Revolutions: A Comparative Analysis of France, Russia and China. Cambridge: Cambridge University Press.

- 1994. Social Revolutions in the Modern World. Cambridge: Cambridge University Press.

Snow, David A., Louis A. Zurcher, Jr., and Sheldon Ekland-Olson. 1980. "Social Networks and Social Movements: A Microstructural Approach to Differential Recruitment." American Sociological Review 45:787-801.

Stryker, Sheldon. 2000. "Identity Competition: Key to Differential Social Movement Participation?" Pp. 21-40 in Self, Identity, and Social Movements, edited by S. Stryker, T. J. Owens, and R. W. White. Minneapolis: University of Minnesota Press.

Sudman, Seymour, Norman M. Bradburn, and Norbert Schwarz. 1996. Thinking about Answers: The Application of Cognitive Processes to Survey Methodology. San Francisco: Jossey-Bass.

Thomson, Marilyn. 1986. Women of El Salvador: The Price of Freedom. Mexico City: Comision de Derechos Humanos de El Salvador (CDHES).

Tilly, Charles. 1978. From Mobilization to Revolution. Reading, Mass.: AddisonWesley.

Ueltzen, Stefan. 1993. Como Salvadoreña que Soy: Entrevistas con mujeres en la lucha. San Salvador: Editorial Sombrero Azul. 


\section{Women's Mobilization}

Vázquez, Norma. 2000. Las Mujeres Refugiadas y Retornadas: Las habilidades adquiridas en el exilio y su aplicación a los tiempos de paz. San Salvador: Las Dignas.

Vázquez, Norma, Cristina Ibáñez, and Clara Murguialday. 1996. Mujeres-montaña: Vivencias de guerrilleras y colaboradoras del FMLN. Madrid: Horas y Horas.

Vilas, Carlos. 1986. The Sandinista Revolution: National Liberation and Social Transformation in Central America. New York: Monthly Review Press.

Wagenaar, Willem A., and Jop Groeneweg. 1990. "The Memory of Concentration Camp Survivors." Applied Cognitive Psychology 4 (2): 77-87.

Walsh, Edward J. 1988. Democracy in the Shadows: Citizen Mobilization in the Wake of the Accident at Three Mile Island. Westport, Conn.: Greenwood.

Wechsler Segal, Mady. 1995. "Women's Military Roles Cross-Nationally: Past, Present, and Future." Gender and Society 9:757-75.

Wickham-Crowley, Timothy. 1992. Guerrillas and Revolution in Latin America: A Comparative Study of Insurgents and Regimes since 1956. Princeton, N.J.: Princeton University Press.

Wiltfang, Gregory L., and Doug McAdam. 1991. "The Costs and Risks of Social Activism: A Study of Sanctuary Movement Activism." Social Problems 69:987-1010.

Witvliet, Charlotte van Oyen. 1997. "Traumatic Intrusive Imagery as an Emotional Memory Phenomenon: A Review of Research and Explanatory Information Processing Theories." Clinical Psychology Review 17 (5): 509-36.

Wolf, Eric R. 1969. Peasant Wars of the 20th Century. New York: Harper.

Wood, Elisabeth Jean. 2003. Insurgent Collective Action and Civil War in El Salvador. Cambridge: Cambridge University Press.

Zerubavel, Eviatar. 1996. "Social Memories: Steps to a Sociology of the Past." Qualitative Sociology 19 (3): 83-99. 